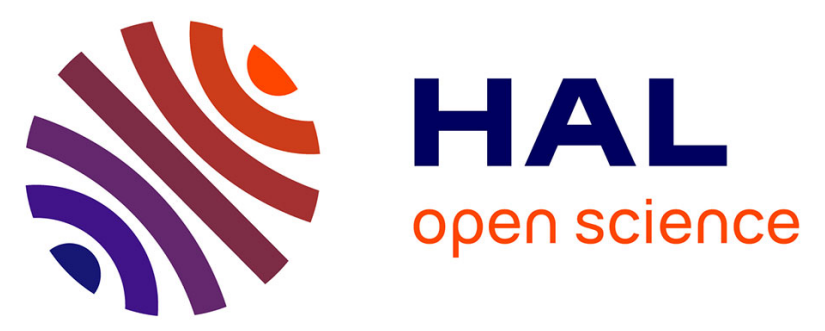

\title{
Polyphase Tectonic Evolution of Fore-Arc Basin Related to STEP Fault as Revealed by Seismic Reflection Data From the Alboran Sea (W-Mediterranean)
}

E. d'Acremont, M. Lafosse, A. Rabaute, G. Teurquety, D. Do Couto, G. Ercilla, C. Juan, Bernard Mercier de Lépinay, S. Lafuerza, J. Galindo-zaldivar, et al.

\section{To cite this version:}

E. d'Acremont, M. Lafosse, A. Rabaute, G. Teurquety, D. Do Couto, et al.. Polyphase Tectonic Evolution of Fore-Arc Basin Related to STEP Fault as Revealed by Seismic Reflection Data From the Alboran Sea (W-Mediterranean). Tectonics, 2020, 39 (3), 10.1029/2019TC005885 . hal-03004274

\section{HAL Id: hal-03004274 https://hal.science/hal-03004274}

Submitted on 15 Apr 2021

HAL is a multi-disciplinary open access archive for the deposit and dissemination of scientific research documents, whether they are published or not. The documents may come from teaching and research institutions in France or abroad, or from public or private research centers.
L'archive ouverte pluridisciplinaire HAL, est destinée au dépôt et à la diffusion de documents scientifiques de niveau recherche, publiés ou non, émanant des établissements d'enseignement et de recherche français ou étrangers, des laboratoires publics ou privés. 


\section{Tectonics}

\section{RESEARCH ARTICLE \\ 10.1029/2019TC005885 \\ Key Points: \\ - The reactivation of the Subduction Tear Edge Propagator fault zone on the southern edge of the Alboran Domain forms the South Alboran Ridge \\ - The style of the present-day structure of the South Alboran region implies an interaction between thick-skinned and thin-skinned tectonics \\ - Undercompacted shales and inherited crustal structures are involved in the structural evolution of the South Alboran Basin}

Correspondence to:

E. d'Acremont,

elia.dacremont@sorbonne-universite.fr

Citation:

d'Acremont, E., Lafosse, M., Rabaute, A., Teurquety, G., Do Couto, D., Ercilla, G., et al. (2020). Polyphase tectonic evolution of fore-arc basin related to STEP fault as revealed by seismic reflection data from the Alboran Sea (W-Mediterranean). Tectonics, 39, e2019TC005885. https://doi.org/ 10.1029/2019TC005885

Received 15 SEP 2019 Accepted 25 FEB 2020 Accepted article online 6 MAR 2020

2020. American Geophysical Union. All Rights Reserved.

\section{Polyphase Tectonic Evolution of Fore-Arc Basin Related to STEP Fault as Revealed by Seismic Reflection Data From the Alboran Sea (W-Mediterranean)}

\author{
E. d'Acremont ${ }^{1}$ (D), M. Lafosse ${ }^{1}$ (D) A. Rabaute ${ }^{1}$ (D) G. Teurquety ${ }^{1,2}$, D. Do Couto ${ }^{1}$, G. Ercilla $^{3}$, \\ C. Juan $^{3}$, B. Mercier de Lépinay ${ }^{4}$, S. Lafuerza ${ }^{1}$, J. Galindo-Zaldivar ${ }^{5,6}$ (D) , F. Estrada ${ }^{3}$ (D), \\ J. T. Vazquez ${ }^{7}$, S. Leroy ${ }^{1}$ (D) J. Poort ${ }^{1}$, A. Ammar ${ }^{8}$, and C. Gorini ${ }^{1}$ \\ ${ }^{1}$ Sorbonne Université, CNRS-INSU, Institut des Sciences de la Terre Paris, ISTeP, Paris, France, ${ }^{2}$ Paris 1 \\ Pantheon-Sorbonne Université, CNRS-Ministère de la Culture, Archéologies et Sciences de l'Antiquité, ArScAn UMR \\ 7041, Nanterre, France, ${ }^{3}$ Instituto de Ciencias del Mar, CSIC, Barcelona, Spain, ${ }^{4}$ Géoazur, Université de Nice-Sophia \\ Antipolis-CNRS-OCA, Nice, Sophia Antipolis, France, ${ }^{5}$ Departamento de Geodinamica, Universidad de Granada, \\ Granada, Spain, ${ }^{6}$ Instituto Andaluz de Ciencias de la Tierra (CSIC-UGR), Granada, Spain, ${ }^{7}$ Instituto Español de \\ Oceanografía (IEO), C.O. Málaga, Fuengirola, Spain, ${ }^{8}$ Faculté des Sciences, Université Mohammed V-Agdal, Rabat, \\ Morocco
}

\begin{abstract}
Since the Miocene, the thinned continental crust below the Alboran Sea and its overlying sedimentary cover have been undergoing deformation caused by both convergence of Eurasia and Africa and by deep processes related to the Tethyan slab retreat. Part of this deformation is recorded at the Xauen and Tofiño banks in the southern Alboran Sea. Using swath bathymetry and multichannel seismic reflection data, we identified different stages and styles of deformation. The South Alboran Basin is made up of Early Miocene to Pliocene sedimentary layers that correlate with the West Alboran Basin depocenter and are dominated by E-W trending folds and thrusts. The Xauen and Tofiño Banks first recorded the phase of extension and strike-slip movement during the slab retreat, followed by the phase of compressional inversion since the Tortonian and are now structured by tight folds, thrusts, and mud bodies. This study proposes that the Banks were located on the southern-inherited Subduction Tear Edge Propagator (STEP) fault related to the westward migration of the Alboran domain during the Miocene. The STEP fault zone, acting as a boundary between the African block and the Alboran block, was located along the onshore Jebha-Nekor fault and the offshore Alboran Ridge and the Yusuf fault zone. Thick-skinned and thin-skinned shortening occurred when slab retreat stopped, and inversion began. The present-day style of the deformation seems to be linked to a decollement level made of undercompacted shale on top of the Ghomaride complex.
\end{abstract}

\section{Introduction}

In a convergence context, fore-arc and back-arc basins undergo extensional, compressional, and strike-slip processes during their evolution, whose impacts on the resulting structures are often difficult to decipher. While extensional and compressional inversion has been extensively studied from a rheological point of view (e.g., Burg \& Ford, 1997; Ziegler et al., 1998), the reactivation of oblique tectonic structures across fore- and back-arc basins has not been widely investigated. This is due to the uncertainty of the geometry and the nature of preexisting lithospheric structures (Munteanu et al., 2011; Martinez-Garcia et al., 2017). On converging plate boundaries, upper-plate extension takes place in a limited amount of space depending on the plate kinematics and on the behavior of the lower plate. Upper-plate extension is considered to be the result of slab roll-back and can be associated with segmentation of the downgoing slab with the development of subvertical lithospheric-scale tear faults at its edges (Govers \& Wortel, 2005; Rosenbaum et al., 2008). In the upper plate, the development of the slab tear triggers the formation of Subduction Tear Edge Propagator (STEP) faults (Govers \& Wortel, 2005). These STEP faults, which migrate in front of the fore- and back-arc basins (e.g., Mancilla et al., 2015; Gallais et al., 2013; Argnani, 2014), accommodate the progressive tear of the slab and its lateral motion. Consistent with their lateral position within the subsidence areas, strike-slip plate boundaries are generally oblique to the direction of convergence, leading to deformation partitioning characterized by lateral and vertical motions (uplift or subsidence). When the conditions of 
back-arc extension are no longer fulfilled (i.e., when the slab-roll back stops or slows down or when there is a change in plate kinematics), the upper-plate extension and the STEP fault movements eventually end. The back-arc basin and its margins can then be reactivated according to the new tectonic regime, and inversion processes can occur (e.g., Billi et al., 2011; Giaconia et al., 2015).

Tectonic reactivation adds complexity to the previous basin structure and infill. The mode and style of deformation during the tectonic reorganization are mainly controlled by kinematics but also by the geometry of the preexisting basin, the nature of the sedimentary infilling, and structural inheritance that make the characterization and quantification of the basin inversion even more complex. Variation in the upper-plate structure and in the strength of the sedimentary cover are associated with changes in the (i) lateral thermal flow, (ii) Moho depth, and (iii) the presence of intermediate weak levels (Cloetingh et al., 2013).

Inversion zones involve the formation of new structures or the reactivation of inherited structures. The obliquity between the preexisting tectonic fabric and the direction of reactivation, which is the consequence of a transpressive behavior (Tikoff \& Teyssier, 1994; Teyssier et al., 1995; Dewey, 2002), leads to a highly distributed deformation in the crust and in the sedimentary cover over time (Fossen \& Tikoff, 1998), associated with block rotations (Wilcox et al., 1973). The Alboran domain (Figure 1) is considered as a thinned continental microplate within the compressive context of the Africa-Europe convergence (Comas et al., 1999; Gutscher et al., 2002; Jolivet et al., 2009; Mauffret et al., 2007; Mauffret et al., 1992). Since the Late Oligocene, the Alboran domain has been shaped by the progressively westward retreat of the Tethyan slab linked to an upper-plate extension (Calvert et al., 2000; Platt et al., 2003; Spakman \& Wortel, 2004; Jolivet et al., 2008). The velocity of the slab roll-back has been decreasing since $20 \mathrm{Ma}$. At $8 \mathrm{Ma}$, the Alboran domain was subjected to tectonic inversion in the context of the Eurasia and Africa convergence (Comas et al., 1999; Do Couto et al., 2014; Jolivet et al., 2008; Martinez-Garcia et al., 2017). The Alboran domain presents two characteristics that can be related to the evolution of the fore-arc basin, (i) the initial extensional stage is represented by the thick $(>8 \mathrm{~km}$ ) Miocene sedimentary cover in the West Alboran Basin (WAB) (Do Couto et al., 2016) including Miocene undercompacted shales that have been the source of mud volcanoes (Comas et al., 1992; Somoza et al., 2012; Do Couto et al., 2016), and (ii) the offshore Alboran Ridge (Leblanc \& Olivier, 1984), the onshore Miocene-Pliocene lateral transfer faults, such as the Crevillente, Alpujarras, and Torcal faults in the northern Betic branch, the Jheba and Nekor faults in the southern Moroccan branch (Martínez-Martínez et al., 2006; Benmakhlouf et al., 2012; Pérez-Valera et al., 2013; Mancilla et al., 2015; Barcos et al., 2015), and the Miocene extensional and transpressive metamorphic domes onshore (Booth-Rea et al., 2012; Jabaloy-Sánchez et al., 2015; Azdimousa et al., 2019), could be the signature of the STEP fault processes.

E-W to NE-SW thrust and folds characterize the South Alboran Sea and form the Xauen-Tofiño Banks, the Frances Pagès Bank, and the Alboran Ridge (Figure 2) (Chalouan et al., 1997). Major questions concerning the emplacement of these structures and the present-day deformation remain open: (i) What was the original geometry of the southern margin of the West Alboran Basin, (ii) how and where is the shortening related to the Africa-Eurasia convergence accommodated, and (iii) what is the influence of the weak Miocene undercompacted shales and muds on the structural style of the Banks. Using seismic reflection and bathymetric data, we characterize the structural and seismic stratigraphic framework of the southern part of the inverted Alboran basin and estimate the shortening rates since the Tortonian. As a result, a scenario for the structural evolution of this region since the Miocene is proposed. We focus on the critical role of the major transfer faults, weak layers, and preexisting crustal structures in the structural evolution of the southern basin.

\section{Geodynamic and Geological Setting}

The Alboran Basin is located at the western entrance of the Mediterranean Sea and is bordered to the north and south by the thickened crust of the Alpine Betic-Rif arcuate belt (e.g., Dewey, 1988; Jolivet \& Faccenna, 2000; Rosenbaum et al., 2002; Mancilla et al., 2015). The Betic-Rif orogenic system (Figure 1) is defined by (i) an internal zone affected by crustal-scale extensional shear zones, which belongs to the Alboran Domain, also recognized as a continental fragment of the AlKaPeCa block (Bouillin et al., 1986; Vergés \& Fernàndez, 2012), and (ii) an external foreland thrust belt composed of Flysch units and Iberian and Maghrebian nappes (e.g., Michard et al., 2002; Chalouan et al., 2008). 


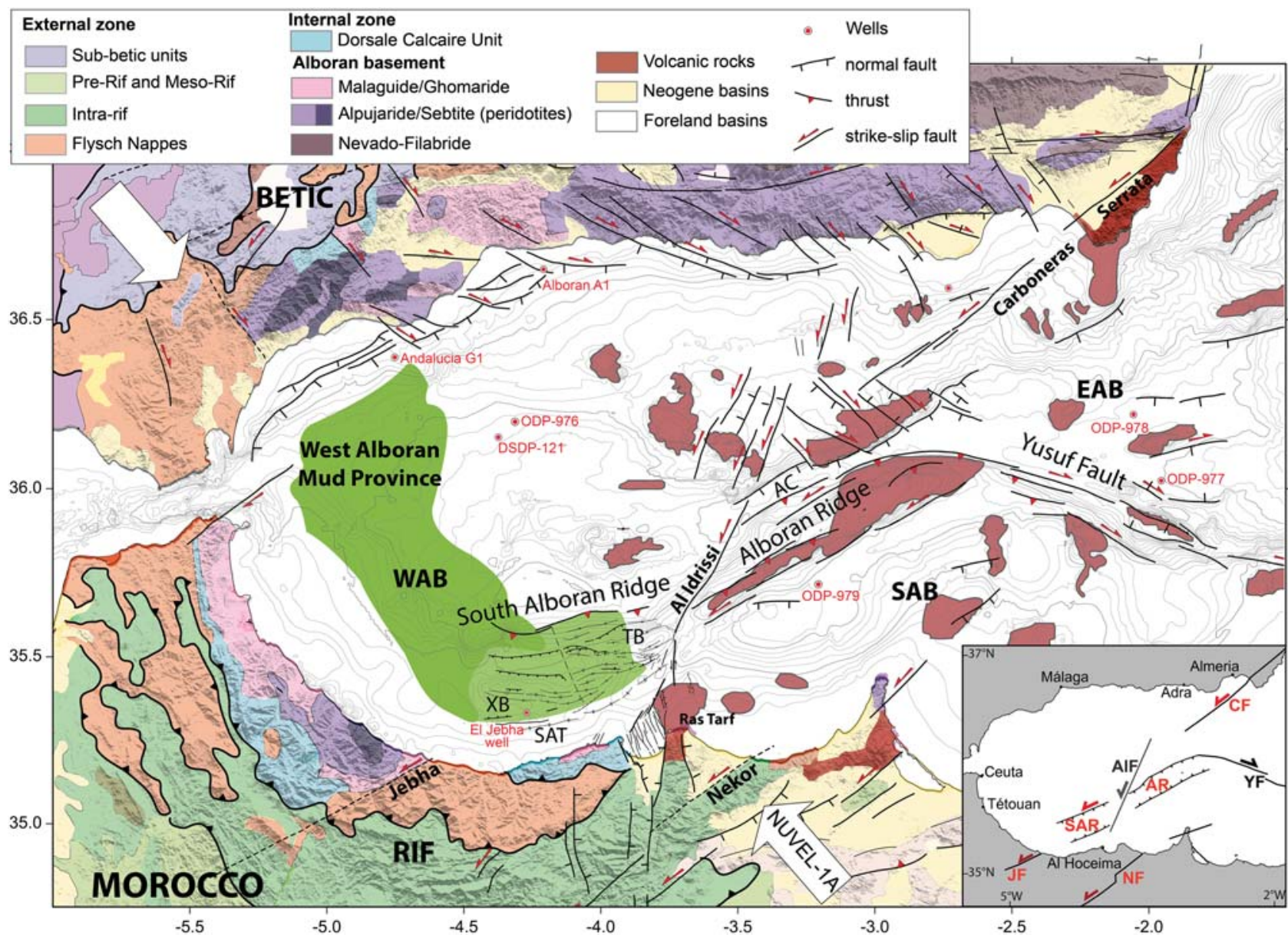

Figure 1. Structural and geological map of the Rif and Betic onshore and of the Alboran basin offshore modified after Chalouan et al. (2008), Martınez-Garcia et al. (2011), Martınez-Garcia et al. (2013), Ballesteros et al. (2008), and Lafosse et al. (2016). The structural scheme in the South Alboran Ridge zone is part of the present study. The West Alboran mud province is shown in dark green and the continuity of this province proposed in this study in light green. Red dots show the location of Leg 161, ODP Sites 121, and industrial Jebha well. AFZ = Adra fault zone; A.C. = Alboran Chanel; AIF = Al Idrissi Fault; AR = Alboran Ridge; $\mathrm{CF}=$ Carboneras Fault; JB = Jebha Fault; NF = Nekor Fault; SAB = South Alboran Basin; SAR = South Alboran Ridge; SAT = South Alboran Trough; T.B. $=$ Tofiño Bank; WAB = West Alboran Basin; XB = Xauen bank; YF = Yusuf Fault. (inset) The Trans-Alboran Shear Zone (TASZ).

The basement of the Alboran Basin is composed of metamorphic rocks similar to those observed onshore in the internal zone of the Betic Cordillera (Sánchez-Gómez et al., 1999; Soto et al., 1999). This continental block was formed by the extension of the upper plate due to retreat of the westward slab in the context of the Africa-Europe convergence since the end of the Oligocene (Gutscher et al., 2002; Mauffret et al., 2007; Jolivet et al., 2009). The continental collision of the Alboran domain with the former Iberian and African passive margin during the Oligocene-Miocene led to the stacking of three metamorphic complexes in the internal zone: the Nevado-Filabride, the Alpujarride/Sebtide, and the Malaguide/Ghomaride complexes from bottom to top (e.g., Crespo-Blanc \& Frizon de Lamotte, 2006). Recent works suggest separating the deepest most metamorphic complex, the Nevado-Filabride complex, from the Alboran domain, based on its provenance at the South Iberian Margin in contrast with the complex overlying Alpujarride and Malaguide rocks of older metamorphism and are derived from the AlKaPeCa block (e.g., Booth-Rea et al., 2015; Rodriguez-Canero et al., 2018; Jabaloy-Sanchez et al., 2018).

The Beni Boussera and Beni-Malek peridotite bodies were intercalated in the Alpujarride/Sebtide complex and in the Rifean external units, respectively, during the pre-Miocene extensive stages of the Maghrebian margin (Afiri et al., 2011; Vázquez et al., 2013). Last, the Dorsale Calcaire, which outcrops mainly in the western part of the Betics and in the Rif (Figure 1), is structurally included between the Malaguide/Ghomaride complex and Flysch units (e.g., Michard et al., 2002; Chalouan et al., 2008). The external zones of the belt are 


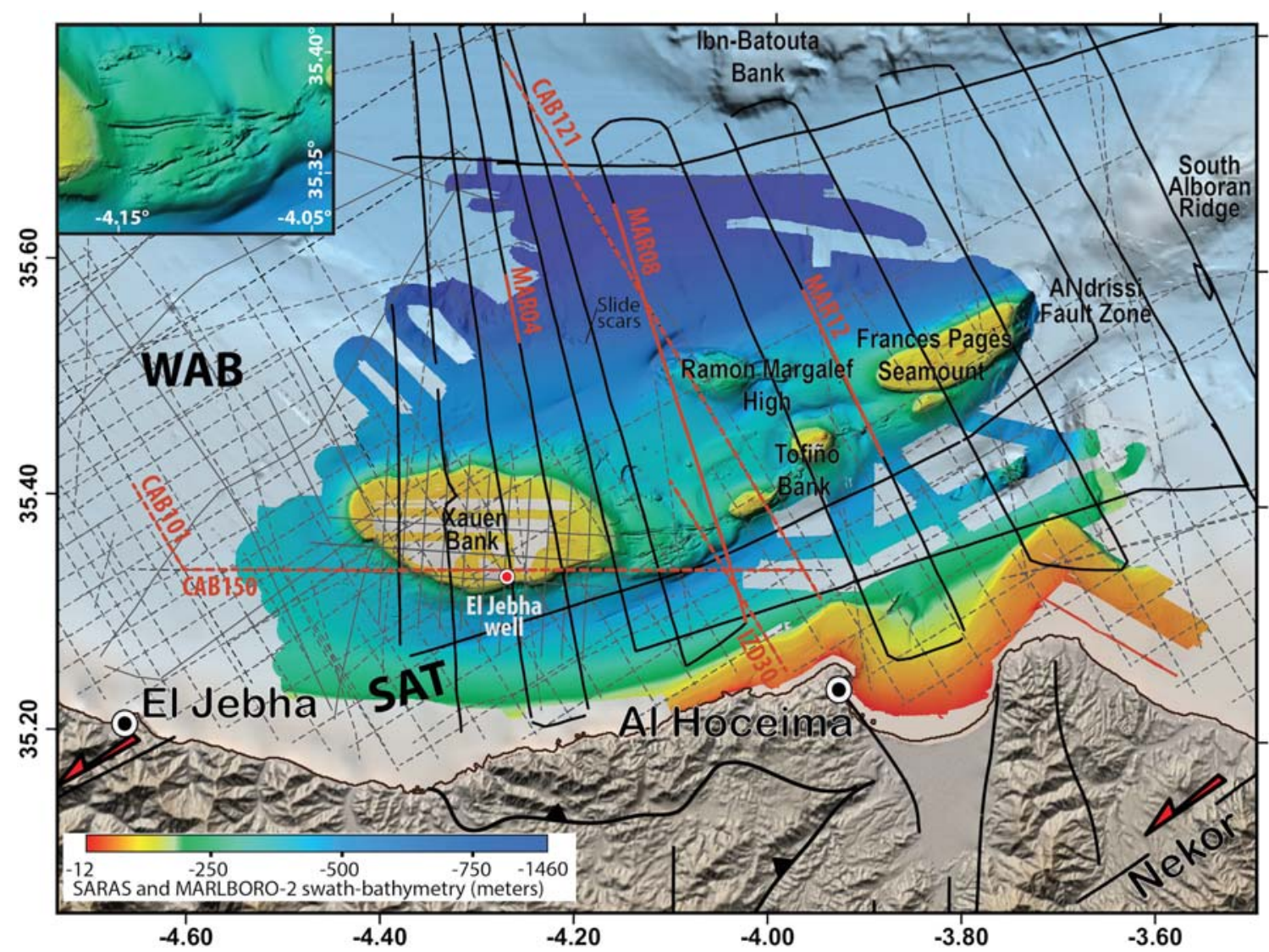

Figure 2. Bathymetric and topographic map of the South Alboran Sea offshore Al Hoceima showing the location of the industrial and academic seismic reflection lines used in this study. High-resolution seismic reflection lines are indicated by solid lines and deep resolution seismic reflection lines by dashed lines. The red transects are presented in this paper. Marlboro-2 seismic reflection lines are indicated by thick black lines. The location of the industrial El Jebha well is shown. (onshore) The topography is extracted from the ASTER GDEM (http://gdem.ersdac.jspacesystems.or.jp/). The offshore area covered by the swath-bathymetry of the SARAS and Marlboro-2 surveys is indicated by a different color scale. (top left inset) Detailed SARAS swath-bathymetric map of the anticline feature between the Xauen and the Tofiño Banks (periclinal termination). SAT = South Alboran Trough; WAB = West Alboran Basin.

composed of Flysch units, and Mesozoic to Miocene Iberian and Maghrebian nappes accreted at the front of the subduction. They are covered by foreland detritic sediments of upper-Tortonian and Pliocene origin (Capella et al., 2017).

Geological and geophysical data support a lithospheric tearing that propagates under the external domains and an E-W direction of extension, in agreement with the westward migration of the slab roll-back (e.g., García-Dueñas et al., 1992; Leprêtre et al., 2013; Spakman \& Wortel, 2004; Bezada et al., 2013; Chertova et al., 2014; Badji et al., 2015; Mancilla et al., 2015; Do Couto et al., 2016; Azdimousa et al., 2019). At the edges of the Alboran domain, metamorphic domes were exhumed as the result of crustal-scale extensional shear from the mid-Miocene to late Miocene (e.g., Lonergan \& Johnson, 1998; Augier et al., 2005; Serrano et al., 2006; Giaconia et al., 2014).

During the Miocene, the deformation of the Alboran Basin was partitioned into normal and strike-slip components to accommodate the slab retreat and the back-arc extension. West Alboran Basin (WAB; Figure 1) is described as a sag basin formed by thermal cooling of the hot asthenosphere (e.g., Do Couto et al., 2016; Hanne et al., 2003; Morley, 1993). Recent studies interpret the WAB as a fore-arc basin located between the orogenic Betic-Rif deformation front and the Alboran volcanic arc that occupies the Central and East Alboran basin (Figure 1; Gómez de la Peña et al., 2018; Booth-Rea et al., 2018). The subsidence in the WAB led to the preservation of the thickest Miocene depocenter (Soto et al., 2008; Do Couto et al., 2014). At the base of the WAB, Lower Miocene undercompacted shales actively feed mud volcanoes (Figure 1) (Pérez-Belzuz et al., 1997; Comas et al., 1992; Talukder et al., 2003; Somoza et al., 2012; Do Couto et al., 2016). 
A broad NE-SW sinistral shear zone called the Trans-Alboran Shear Zone cross cuts the Alboran domain (Figure 1, inset) (Leblanc \& Olivier, 1984). It connects to the Jebha and Nekor fault systems at the Moroccan margin (Chalouan \& Michard, 2004; Benmakhlouf et al., 2012; Capella et al., 2017). Offshore, the Alboran Ridge, which is part of the Trans-Alboran Shear Zone, is a $60 \mathrm{~km}$ long transpressive NE-SW elongated tectonic discontinuous structure (Muñoz et al., 2008; Ballesteros et al., 2008), made of Miocene and Pliocene sedimentary and volcanic rocks. It is locally intruded by a volcanic body in its eastern part (Ammar et al., 2007; Mauffret et al., 2007; Chalouan et al., 2008; Maad et al., 2010), while its southern termination, called the South Alboran Ridge (SAR), corresponds to a series of Mio-Pliocene sigmoid antiforms and synforms accommodating left lateral motion and uplift (Bourgois et al., 1992; Comas et al., 1992; Chalouan et al., 1997; Mauffret et al., 2007; Galindo-Zaldivar et al., 2018).

NNE-SSW sinistral faults (Al Idrissi fault zone) cross the central Alboran Sea and continue onshore through the Adra and Al Hoceima regions (Figure 1) (e.g. d'Acremont et al., 2014; Lafosse et al., 2016, 2018; Gràcia et al., 2019). At present, the Al Idrissi fault zone and the WNW-ESE dextral Yusuf fault system (Figure 1) (Koulali et al., 2011) are consistent with a tectonic indentation of the African rigid plate toward the NW (Estrada et al., 2018).

Around the Alboran Ridge, an extension phase followed by an inversion phase is evidenced by (i) the presence of syntectonic wedges at the hanging wall of normal faults, interpreted as related to the early-Miocene extension episode (Martinez-Garcia et al., 2013, 2017), and by (ii) the presence of folds and thrusts interpreted as due to the inversion of the WAB (Bourgois et al., 1992; Martinez-Garcia et al., 2013, 2017).

\section{Data and Methods}

\subsection{Data}

The data set comprises academic and industrial 2-D seismic reflection lines and swath-bathymetric data covering an area of around $7,000 \mathrm{~km}^{2}$ in the southernmost West Alboran Basin and the Moroccan margin (Figure 2). Two academic surveys were exploited: the Marlboro-1 survey onboard the R/V Côtes de la Manche (CNRS/INSU) in July 2011 and the SARAS survey onboard the R/V Ramon Margalef (Instituto Español de Oceanografía) in August 2012. During the SARAS survey, swath bathymetry (Kongsberg multibeam echosounder EM710) was acquired (Figure 2). The EM710 operates at sonar frequencies in the 70 to $100 \mathrm{kHz}$ range. The cell size of the processed grid is $15 \mathrm{~m}$. During the Marlboro- 1 survey, a $25 \mathrm{~m}$ spaced, 12-channel streamer recorded 1,100 km of high-resolution seismic reflection data. The seismic source was a mini-GI SODERA Air gun (24 ci/24 ci) shooting every $6 \mathrm{~s}$ (shot spacing $12.5 \mathrm{~m}$ ) at a pressure of 120-140 bars. The geometry of the acquisition allows 12 -fold coverage. The dominant frequency of the source was 80 to $100 \mathrm{~Hz}$, yielding a vertical resolution of around $10 \pm 5 \mathrm{~m}$, depending on depth. Data were processed using Seismic Unix and Geocluster seismic (C) software in a standard sequence. The data were stacked, filtered, and migrated with a constant velocity $(1,500 \mathrm{~m} / \mathrm{s})$. The processed seismic data and bathymetric coverage were imported into a Kingdom Suite $\subset$ project for interpretation.

The Marlboro-1 seismic lines provide an image of the basin down to $2-3.5 \mathrm{~km}$ below the seafloor. In addition to these high-resolution seismic reflection data, we used deep-penetration multichannel seismic lines from an industrial source (CAB lines, courtesy of ONHYM). These lines provide a depth record $6 \mathrm{~km}$ below the seafloor, down to the basement top, and make it possible to see deep reflectors below the top basement. These data combined with the complete available seismic reflection lines (see d'Acremont et al., 2014; Juan et al., 2016; Lafosse et al., 2016) form a dense network throughout the West Alboran basin and the north Moroccan margin (Figure 2).

In section 4, approximate dips and thicknesses are computed from previously estimated $P$ wave velocity values (Figure 3; Talukder et al., 2003; Martinez-Garcia et al., 2013, 2017). One seismic line (CAB121) was converted to depth using average acoustic velocities shown in Figure 3 to estimate the magnitude of shortening.

\subsection{Seismic Stratigraphy}

The stratigraphic information from academic offshore wells (ODP Sites 976 to 979 and DSDP Site 121) and industrial wells (Andalucía-G1, Alborán-A1, Andalucía-A1, El Jebha, and Nador 1) was used to calibrate the 


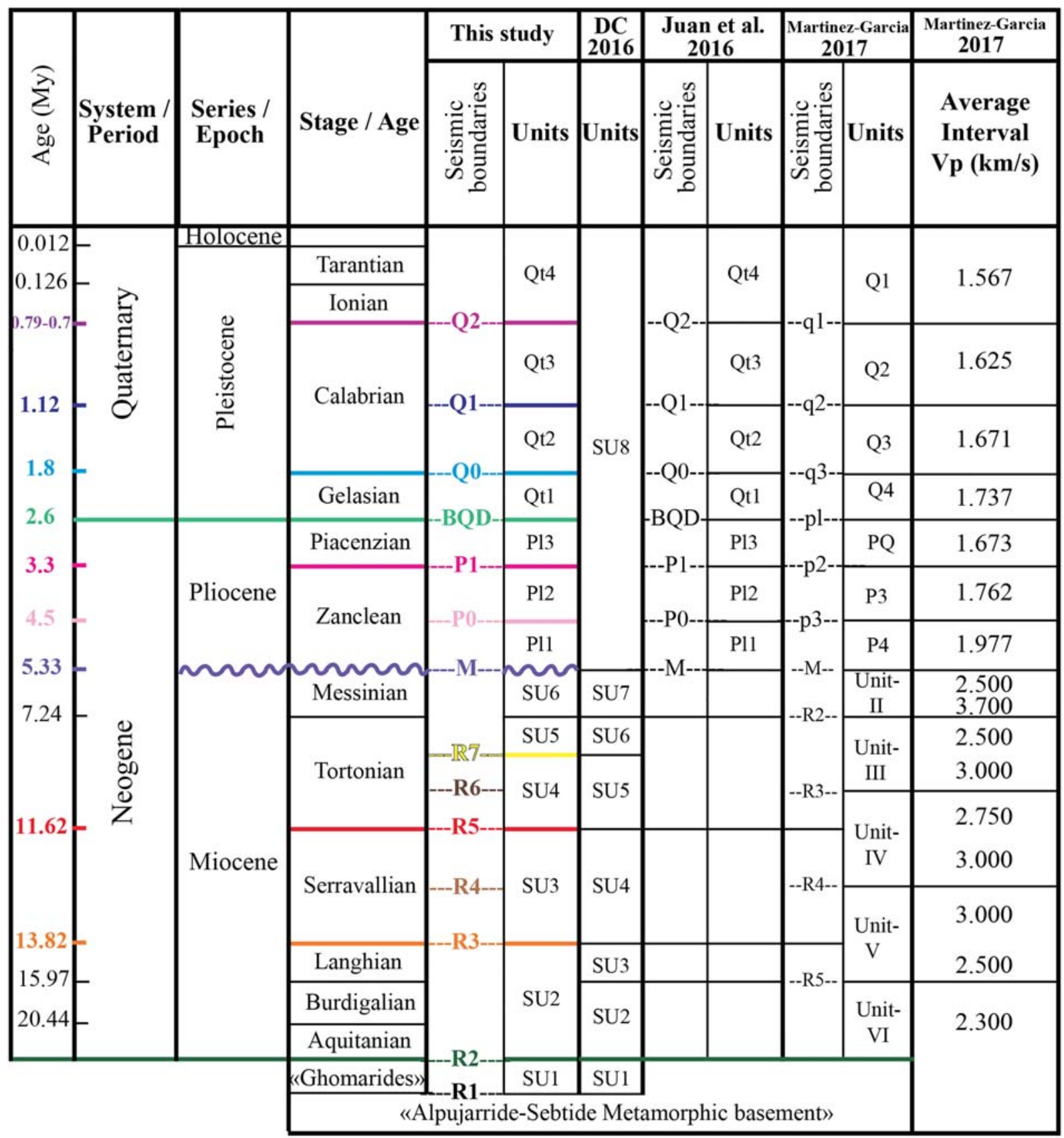

Figure 3. The seismo-stratigraphic units defined in this study and correlations with previous studies (Do Couto et al., 2016; Juan et al., 2016; Martinez-Garcia et al., 2017), the average Vp interval comes from Martinez-Garcia et al. (2017). The seismic stratigraphic boundaries were calibrated based on data from scientific wells DSDP 121 and ODP 976-979 (Armentrout et al., 1991; Comas et al., 1996), from Andalucia G1, Habibas 1, and El Jebha industrial wells (e.g., Do Couto et al., 2016; Martinez-Garcia et al., 2017) and from local-regional and global-scale studies (see in Juan et al., 2016).

seismic profiles and estimate the velocity values (Figures 3 and 4). Based on Juan et al. (2016) and Do Couto et al. (2016), 14 horizons from the early Miocene to the Holocene were identified in the available seismic reflection lines that cross the Xauen and Tofiño Banks (Figures 2 to 4). All the intervals recognized by these authors were used. However, for the Miocene intervals, we merged the Aquitanian, Burdigalian, and Langhian units into a single SU2 unit compared to the study of Do Couto et al. (2016) (Figure 3). The different seismic units and bounding discontinuities are well defined in the post-Miocene sequence thanks to the available high-resolution lines and log information (e.g., Juan et al., 2016; Martinez-Garcia 


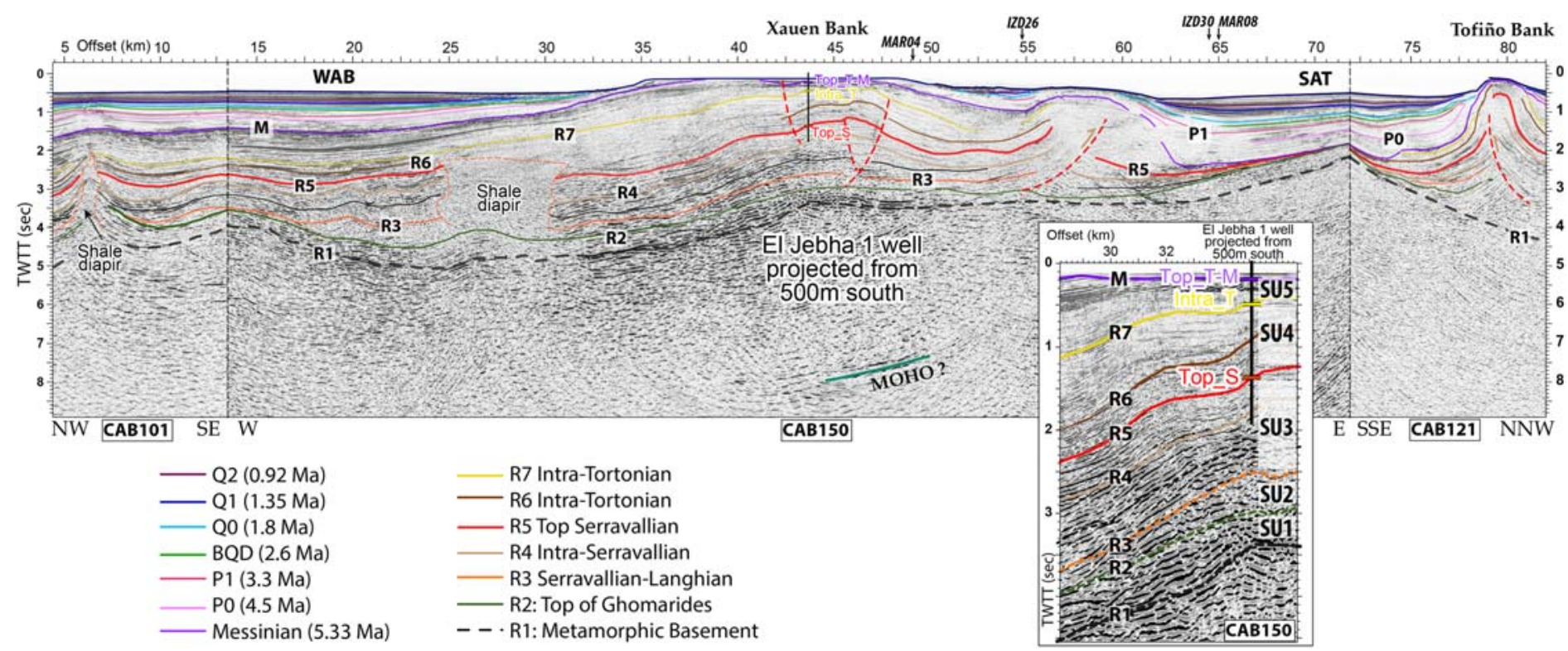

Figure 4. Composite seismic reflection lines CAB101, CAB150, and CAB121 crossing the location of the El Jebha well that make it possible to follow the distinct horizons across the West Alboran Basin, the Xauen Bank, and the Tofiño Bank. A correlation is made with the El Jebha well and with the study of Do Couto et al. (2016). Arrows with seismic line names indicate line intersections. SAT $=$ South Alboran Trough; WAB $=$ West Alboran Basin. Location of the profile in Figure 2. See Figure 3 for information on the seismic stratigraphic boundaries.

et al., 2017). For the pre-MSC sequence, the horizons were tentatively calibrated despite the decrease in seismic resolution with depth (Do Couto et al., 2016). We used the micropaleontological ages of the sedimentary sequences from Do Couto et al. (2016) and the average interval velocity computed by Martinez-Garcia et al. (2017). In the WAB, at the top of the metamorphic basement (SU0; Figure 3), Do Couto et al. (2016) interpreted a prerift unit (SU1) as the topmost Malaguide/Ghomaride nappe composing the first unit of the Alboran Domain. This SU1 unit can be tracked from the WAB to the bottom of the Xauen and Tofiño Banks (Figure 4). SU1 is characterized by high-amplitude, low-frequency discontinuous reflectors (Figure 4).

Above this prerift formation, five Miocene units were defined, from the Aquitanian to the Messinian (Figure 3). The Miocene subsidence phases were based on the unconformities and thickening of the sedimentary sequences from the R2 to the M horizons (Figure 3) (Do Couto et al., 2016). The SU2 unit is limited at its bottom by the SU1 unit and is marked by extensively deformed reflection packages and local variations of thickness. This seismic unit was reached by drilling in the Alboran-A1 borehole (Comas et al., 1999; Iribarren et al., 2009). It is composed of greenish to reddish shales above a basal marine conglomerate (Do Couto et al., 2016). Undercompacted shales dated as Langhian can be seen in this unit. Mud volcanism observed in the WAB is rooted in the deep unit SU2, the top of which is the R3 horizon (shale diapir; Figure 4). The Xauen Bank has been drilled by the El Jebha well (Morley, 1993; Chalouan et al., 1997; Ammar et al., 2007). The El Jebha well was used to calibrate the location of three horizons in the study area: the top Serravallian seismic horizon (R5), an intra-Tortonian seismic horizon (R7), and a Top-Tortonian-Messinian seismic horizon (M; Figures 3 and 4). The "M" reflector is a key stratigraphic marker, as the uppermost Miocene sediments in the Alboran Basin were affected by the Messinian Salinity Crisis (e.g., Estrada et al., 2011). This reflector makes it possible to follow this event at the basin scale. It is characterized by a high-amplitude, low-frequency signal and by an erosional surface on the shelf, highs, and central basins. Isochore maps of the Miocene unit show a continuous depocenter in the WAB whose direction changes southward from an NNW-SSE trend to W-E trend and whose thickness ranges between 5 and $8 \mathrm{~km}$ (Figure 5a). This depocenter ends to the east in the area of the Al Idrissi fracture zone.

The six Plio-Quaternary seismic stratigraphic boundaries were based on the work of Juan et al. (2016) (Figure 3). The isochore map of the Plio-Quaternary unit emphasizes a thin area $(<200 \mathrm{~m})$ in an ENE-WSW direction, evidence for the uplift of the Xauen-Tofiño banks (Figure 5b). Three depocenters 

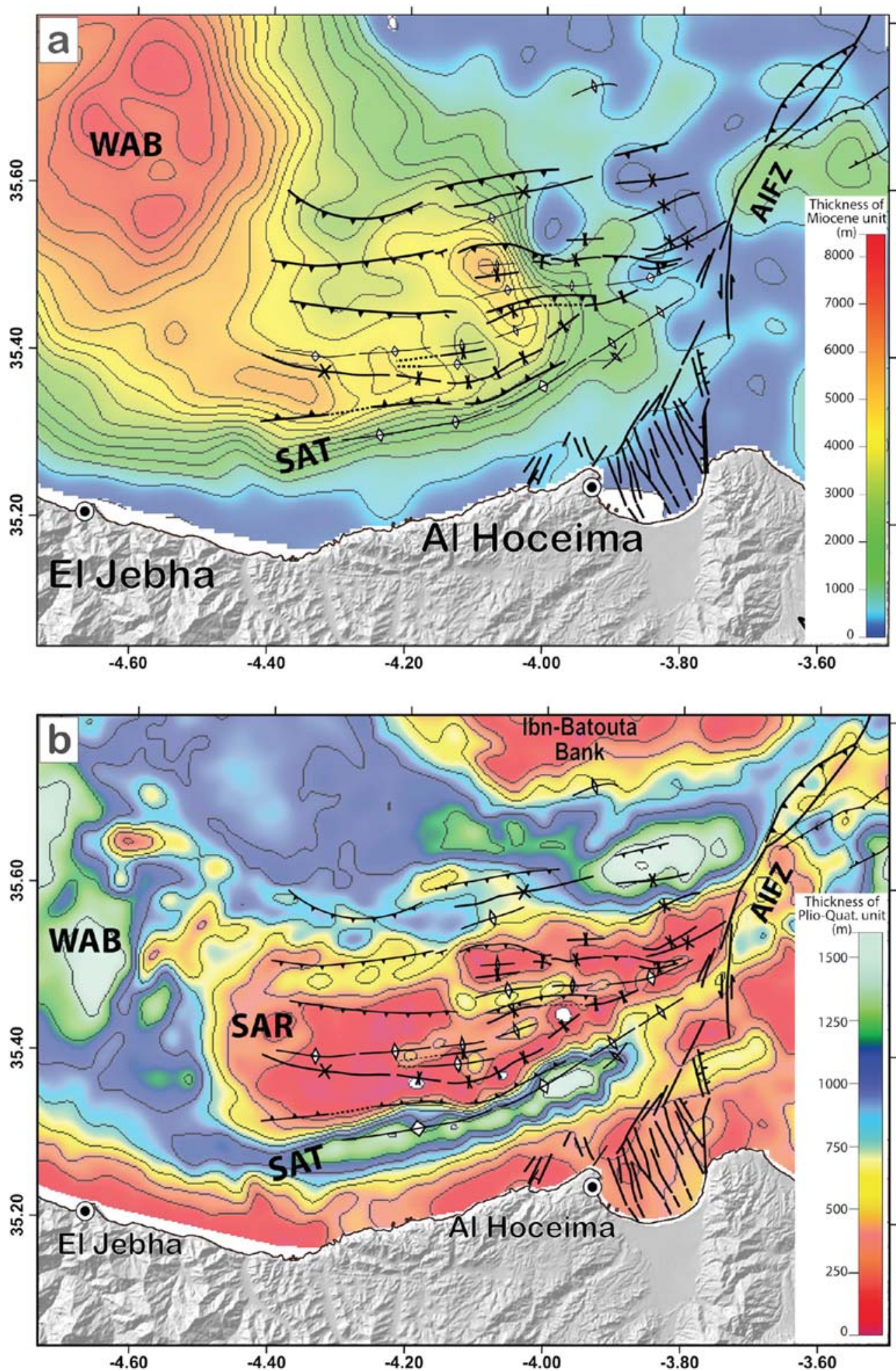

Figure 5. Isochore maps of (a) Miocene (mean velocity 2,750 m/s) and (b) Plio-Quaternary (mean velocity 1,720 m/s) offshore Al Hoceima, interpolated from the 2D seismic dataset (Fig. 2; in seconds two-way travel time). (onshore) Tectonic structures are from Van der Woerd et al. (2014) and Poujol et al. (2014). (offshore) Tectonic structures are from the present study and from Lafosse et al. (2016). (onshore) The topography is extracted from the ASTER GDEM (http://gdem.ersdac.jspacesystems.or.jp/). AIFZ = Al Idrissi Fault Zone; SAT = South Alboran Trough; WAB = West Alboran Basin. Legend in Figure 1. 


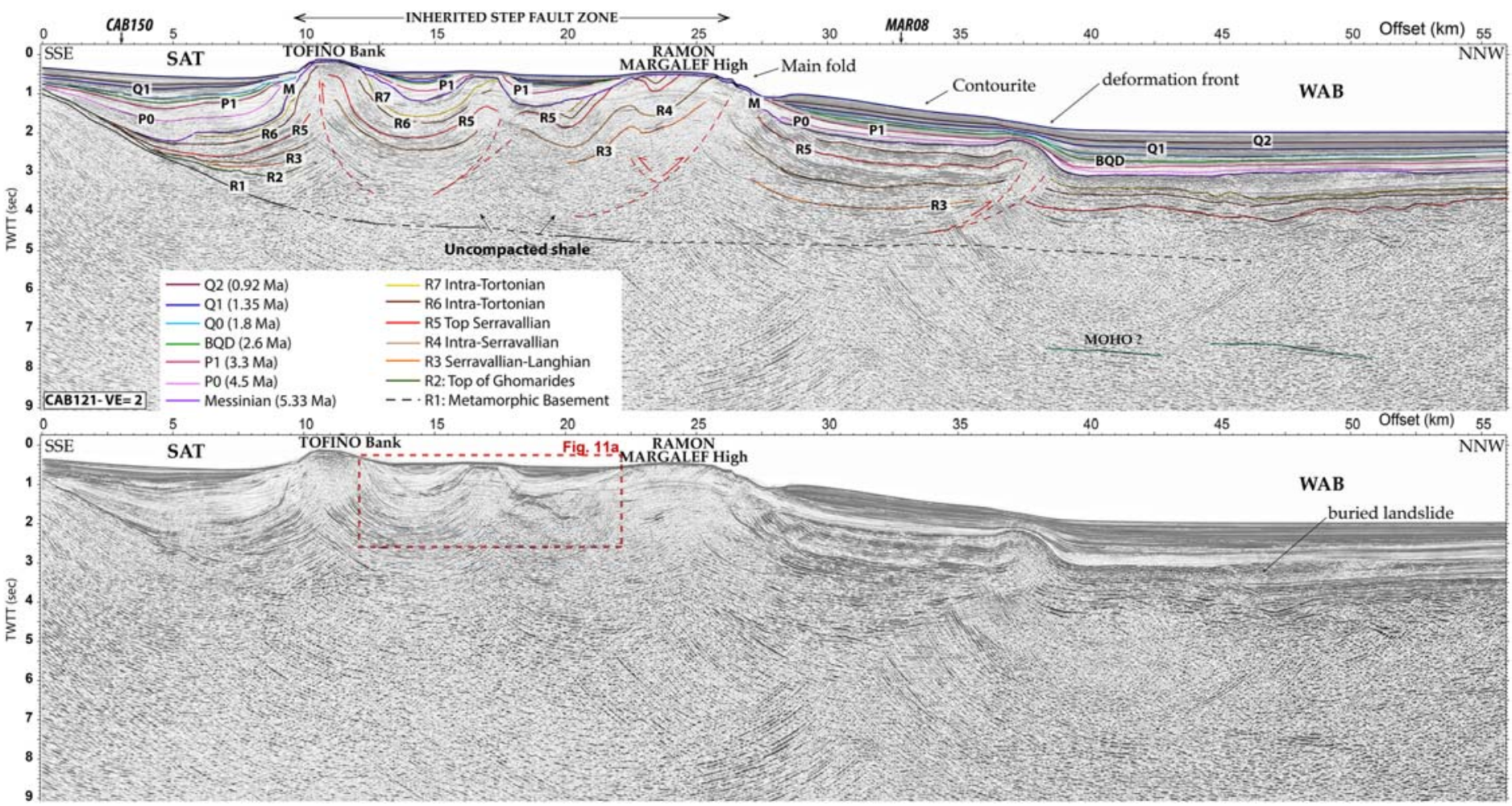

Figure 6. Interpreted and uninterpreted $C A B 121$ seismic profile offshore Morocco showing the architecture of the Tofiño Bank and Ramon Margalef High. $\mathrm{SAT}=$ South Alboran Trough; $\mathrm{WAB}=$ West Alboran Basin. Arrows with seismic line names indicate line intersections. Red dashed lines indicate thrusts. Location of Figure 11a. Location of the profile in Figure 2.

are highlighted: in the west, the NW-SE WAB; in the south, the South Alboran Trough (SAT; also known as Al Hoceima Valley; Juan et al., 2016 and Ercilla et al., 2019); and in the north, the continuity of the WAB confined between the SAR and the Ibn Batuta high (Figures 1 and 5b). These depocenters can reach a thickness of 1,500 $\mathrm{m}$ (Figure 5b). During the Plio-Quaternary period, the circulation of Mediterranean water masses, after the opening of the Strait of Gibraltar erosion, led to the remobilization of sedimentary units followed by redeposition. These processes are partly responsible for the contourite drifts and erosive features observed in the entire Alboran Sea (Ercilla et al., 2016; Juan et al., 2016; Ercilla et al., 2019). In the study area, erosional features are visible at the foot of the structural highs (moat at the northern edge and contourite channel at the southern edge of the SAR; Figures 6 to 8).

\section{Results}

The SAR corresponds to a long ENE-WSW Mio-Pliocene folded structure (Figures 1 and 2). It exhibits several highs from west to east, the largest of them being the Xauen Bank, the Tofiño Bank, the Ramon Margalef High, and the Francesc Pagès Seamount (Figure 2). Today, it is limited to the east by the Al Idrissi fault zone and to the west by the WAB (Figure 1). Six seismic reflection profiles are presented to depict the Mio-Pliocene local tectonic evolution of the SAR (Figure 2).

\subsection{The Southern Boundary of the SAR}

The SAR is limited to the south by the SAT. The SAT is characterized by a southern asymmetric syncline that can be traced $50 \mathrm{~km}$ from east to west (Figures 6 to 11). Its northern limb is steeper than its southern limit. At the Moroccan margin, the top basement (R1) and the top of the Ghomaride (R2) are characterized by prominent northward, seaward, dipping seismic reflectors (Figures 6 and 8). At the southern limb of the SAT, the $\mathrm{R} 3$ to $\mathrm{M}$ reflectors progressively onlap onto the $\mathrm{R} 2$ reflector, and the corresponding seismic units terminate updip by onlapping onto the top of SU1 unit (R2; Figure 8). On the northern limb of the syncline, the SU2 and SU3 units (from R2 to R5 unconformities) exhibit inclined growth strata with a cumulative wedge 

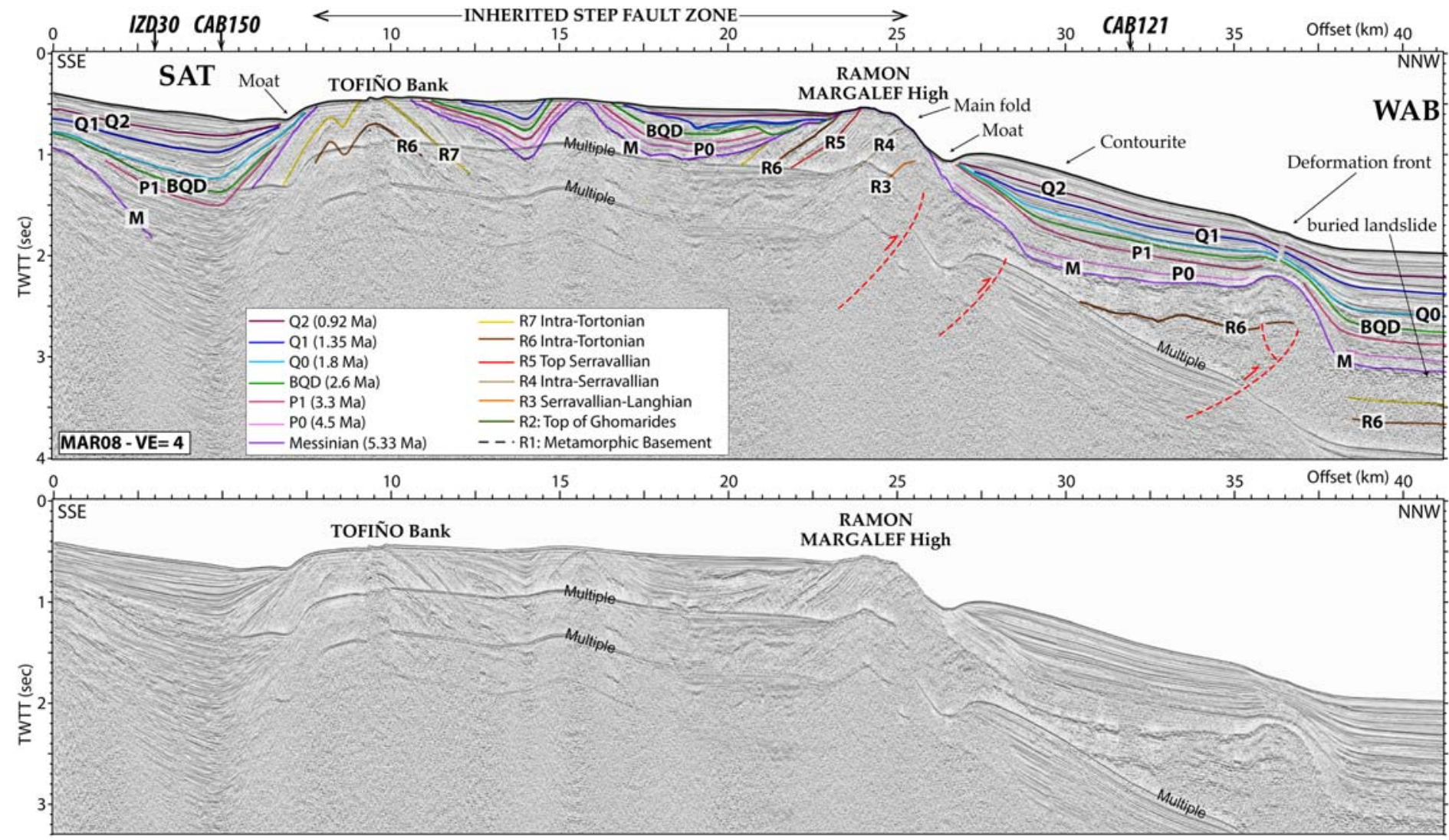

Figure 7. Interpreted and uninterpreted MAR08 seismic profile offshore Morocco showing the architecture of the Tofiño Bank and Ramon Margalef High $\mathrm{SAT}=$ South Alboran Trough; WAB $=$ West Alboran Basin. Arrows with seismic line names indicate line intersections. Location of the profile in Figure 2.

toward the Tofiño and Xauen Banks (Figures 6 and 8). There is no evidence of variation in thickness in the seismic units between R5 and M reflectors (SU4 to SU6), except related to the Messinian Erosional Surface (Figure 8). Similarly, the Plio-Quaternary sedimentary succession in the SAR presents some variations in thickness (Figures 6 to 8 ) and is pinched toward the margin and the SAR. The toplaps and/or offlaps of the P0 to Q2 reflectors observed at the southern limb of the SAT may be due to erosional processes linked to contourite processes. However, the visible dip of the Plio-Quaternary reflectors is steep, and the dip of the $\mathrm{M}$ to BQD horizons is steeper than that of horizons Q0 to Q2 (Figure 7). These geometries suggest

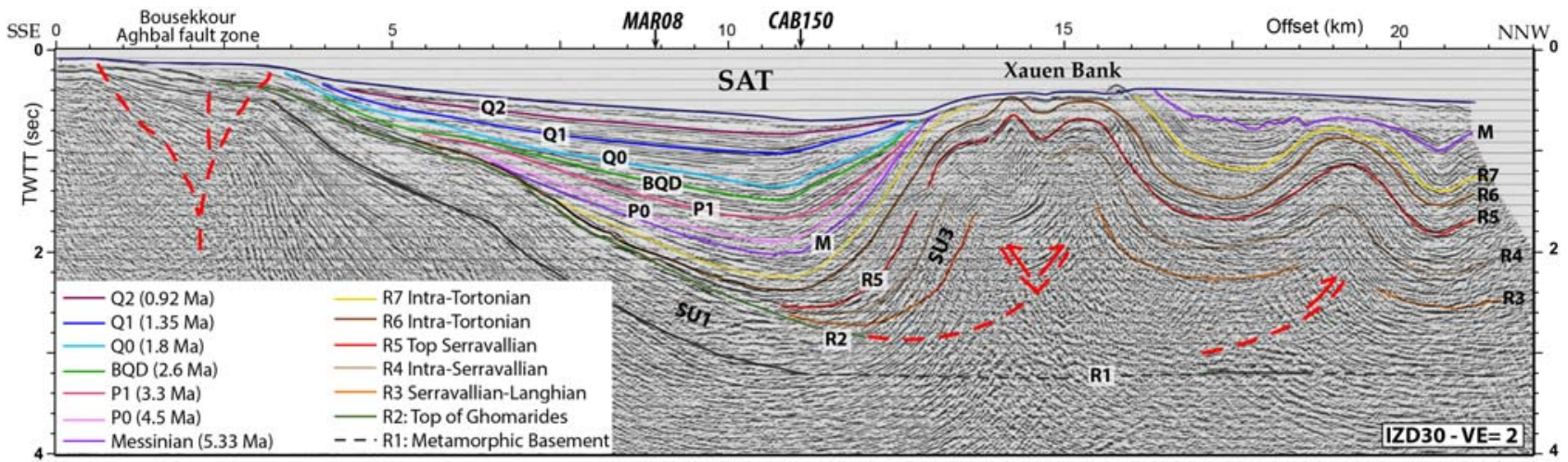

Figure 8. Interpreted IZD30 seismic profile offshore Morocco showing the sedimentary architecture of the Xauen Bank. SAT $=$ South Alboran Trough. Arrows with seismic line names indicate line intersections. Location of the profile in Figure 3. 


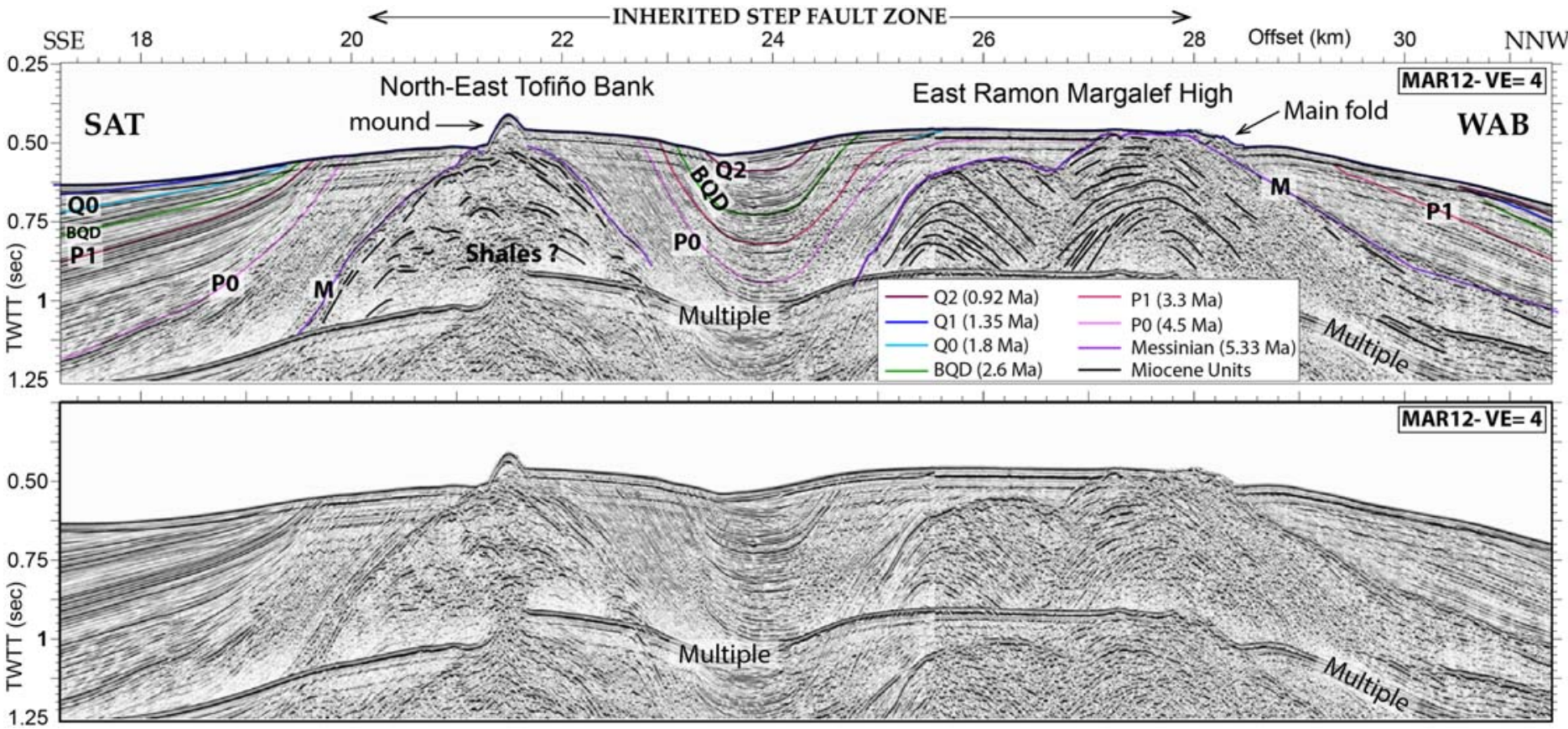

Figure 9. Interpreted and uninterpreted MAR12 seismic profile offshore Morocco showing the architecture of the North-East Tofiño Bank and of the East Ramon Margalef High. SAT $=$ South Alboran Trough; WAB = West Alboran Basin; VE = Vertical exaggeration. Location of the profile in Figure 2.

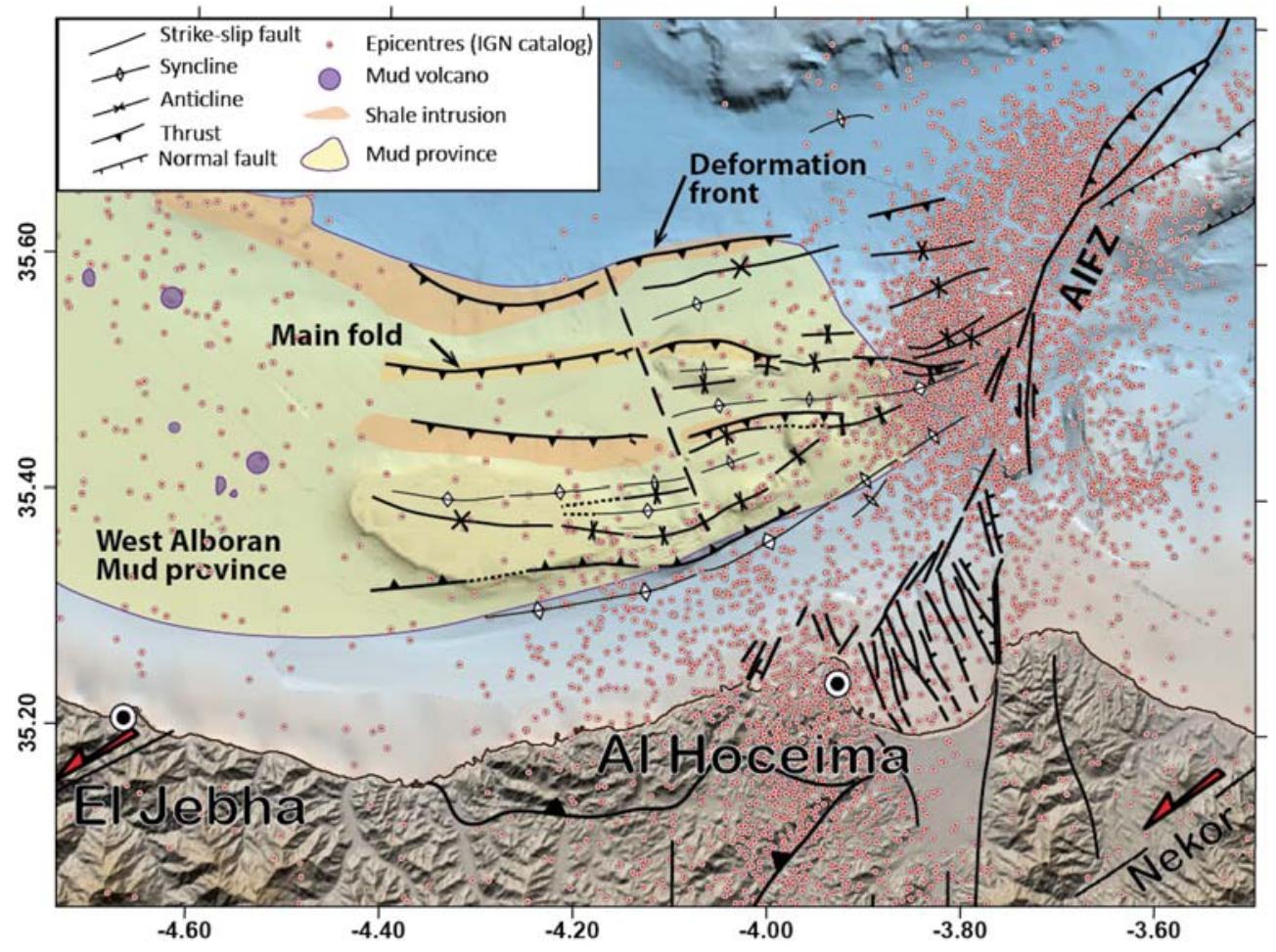

Figure 10. Structural map of the study area. The West Alboran mud province is shown in yellow. Pink dots indicate the epicenters of seismicity between 1964 and 2017 (Instituto Geografico Nacional IGN database). (onshore) Tectonic structures are from Van der Woerd et al. (2014) and Poujol et al. (2014). (offshore) Tectonic structures are from the present study and from Lafosse et al. (2016). (offshore) Bathymetry from SARAS and MARLOBO-2 surveys over the GEBCO bathymetry (https://www.gebco.net/). (onshore) The topography is extracted from the ASTER GDEM (http://gdem.ersdac.jspacesystems.or.jp/). 
Table 1

Estimation of the Shortening in the Study Areas During Different Geological Periods Based on This and Other Studies

\begin{tabular}{lllll}
\hline Author & Period & Area & Shortening $(\mathrm{km})$ & Shortening rate (mm/yr) \\
\hline This study & BQD-present day & SAR & $\sim 0.5$ & $\sim 0.2$ \\
This study & M-BQD & SAR & $\sim 1.7$ & $\sim 6.3$ \\
This study & R5-M & SAR & $\sim 8.5$ & $\sim 1$ \\
This study & R5-present day & SAR & $\sim 3.5$ & $\sim 0.7$ \\
Ammar et al. (2007) & M-present day & Central Alboran Ridge & $\sim 2$ & $\sim 0.6$ \\
Martinez-Garcia et al. (2017) & Since 3.3 Ma & NE and SE Alboran Ridge & $\sim 1-1.5$ \\
Martinez-Garcia et al. (2017) & Since 3.3 Ma & Rif & $\sim 50$ & $\sim 0.6$ \\
Chalouan et al. (2008) & Since Tortonian to present day & Abubacer fault system & $\sim 3$ & $\sim 0.3-0.4$ \\
Giaconia et al. (2015) & Since latemost Tortonian to Messinian & Moroccan marine gateways & $\sim 10-15$ \\
Flecker et al. (2015) & Late Miocene & Rif & & $\sim 1-2.3$ \\
Meghraoui et al. (1996) & Since Pleistocene & &
\end{tabular}

Note. See Figure 3 for ages used in this study.

active uplift of the Moroccan margin and growing of the Xauen-Tofiño Banks with stages of acceleration and of deceleration during the Plio-Quaternary period.

\subsection{The SAR}

Shortening is distributed from east to west over the 10 to $25 \mathrm{~km}$ wide SAR structure, composed of a series of two to four, $5 \pm 1 \mathrm{~km}$ wavelength anticlines (Figures 6 to 10). These series of anticlines and synclines associated with blind thrusts structure the Xauen-Tofiño Banks and Ramon Margalef High (Figures 6 to 10). The asymmetry of the folds is compatible with the presence of a vergence thrust mainly northward verging thrust. Anticlines overlie mainly blind southward dipping thrust faults and some northward dipping thrust fault (Figures 6 to 10).

From the West Alboran Basin and the SAT, we were able to track the stratigraphic sequences (Figure 4). In the SAR region, the available deep seismic profiles (Figure 4) suggest the presence of the Ghomarides unit (SU1) and the complete Miocene stratigraphic sequences (SU2 to SU5; Figure 4). From the basement (R1) to the Messinian reflectors (M), although it is difficult to identify and track the SU1 and SU2 in all lines without deep calibration, the El Jebha makes it possible to calibrate the top Serravallian reflector (R5; Figure 4). Two major variations in thickness in the Miocene seismic units can be observed (Figure 10a; offset 13 to $17 \mathrm{~km}$ ): (i) a sedimentary thickening toward the north in the Serravallian units (below R5) and (ii) a sedimentary thinning toward the north in the Tortonian units (above R5) and until P1. These variations in thickness may indicate an inversion of the fault, first normal and then inverse.

The crest of the northern Ramon Margalef anticline has been strongly eroded. The associated thrust appears to reach the seabed, allowing the outcropping of the Miocene unit (Figures 6 and 7). We define this zone as the main fold located at the same latitude as the Ramon Margalef High (Figures 6, 7, and 9). The Miocene anticlines and synclines located at the backlimb of this main fold (offset 18-27 km; Figure 6) are tilted southward due to the conjugated back thrust of the major northward verging thrust (Figures 6 and 7). Above the $M$ reflector, the Plio-Quaternary units show variations in thickness, with missing units indicating nondeposition or erosive hiatuses at the top of the highs into perched synclines and eroded anticlines (Figures 7 and 11a). The Messinian erosional surface is clearly visible on the SAR, where the top Miocene anticlines are eroded (Figures 6, 7, 9, and 11a). The folding is more pronounced in the Miocene units than in the Plio-Quaternary units. However, the lateral variation in thickness in the Plio-Quaternary units is representative of growth strata. Similarly, the presence of unconformities and tilted reflectors outside the areas with contourite deposits is evidence that the deformation is also recorded in those units (Figure 11a). Moreover, the axial planes of the Miocene folds are different from those of the Plio-Quaternary folds (Figure 11a). At the top of the Xauen Bank, from the M to the BQD reflectors, the seismic units are folded to form a tilted syncline which shows variations in thickness, indicating syncompressive deposits (Figure 11a). Two major unconformities were identified: the Messinian (M; $5.33 \mathrm{Ma}$ ) and the base of the Quaternary Deposits (BQD; $2.6 \mathrm{Ma}$ ) (Figures 7 and 11a). The syncline basin can be interpreted as a piggyback basin related to the activity of the south-verging major thrusts. 

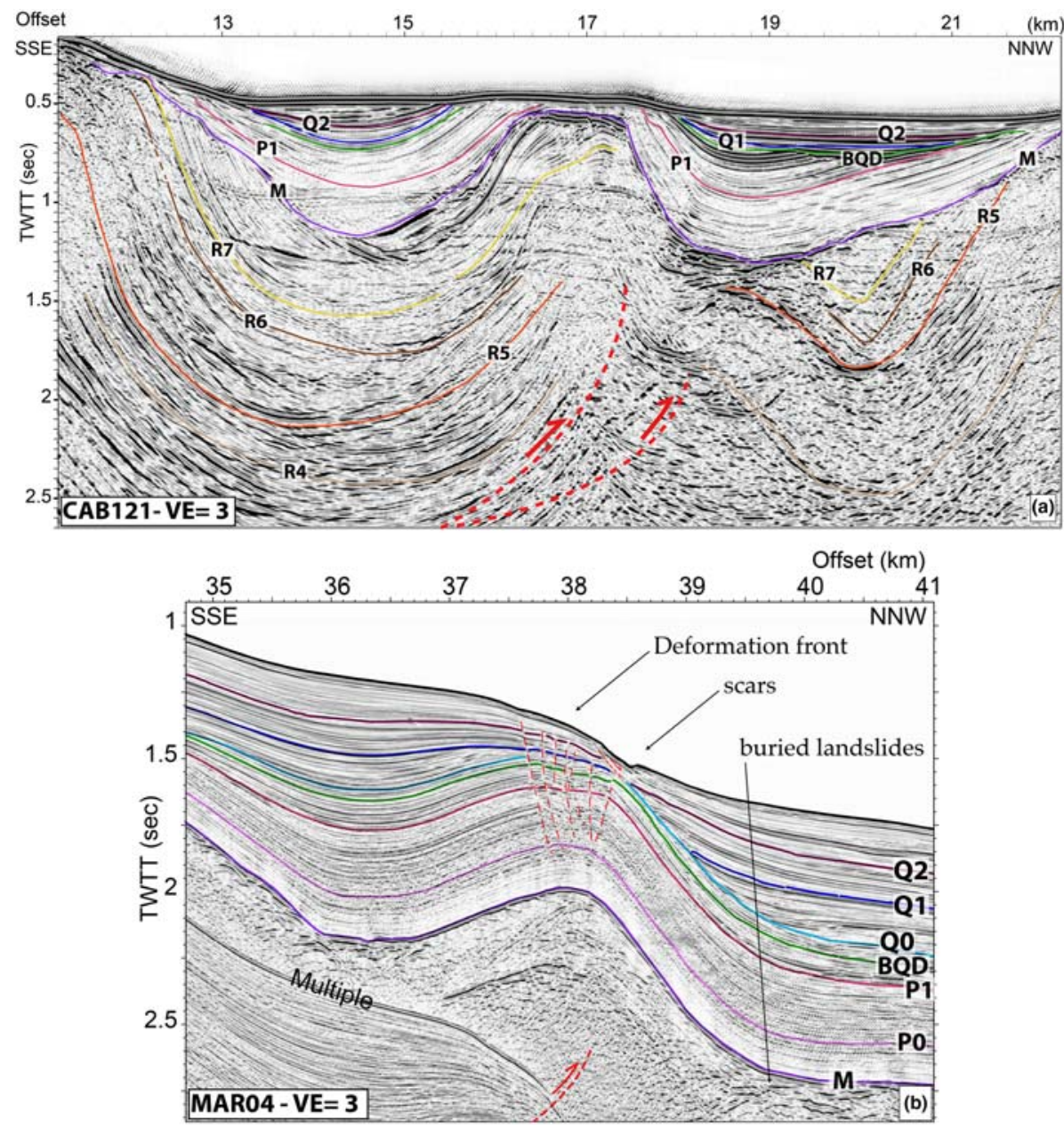

Figure 11. (a) Detail on seismic lines CAB121 on the perched synclines (location in Figure 3) and (b) MAR04 on the frontal deformation (location in Figure 2). See legend in previous figures. VE = Vertical exaggeration.

Northeast of Tofiño Bank, the core of the anticline composed of Miocene units is characterized by chaotic seismic facies (Figure 9). The limbs of this anticline are slightly asymmetric with steeper bedding dips in the forelimb. At the seafloor, a mound is located immediately above the anticline at the hinge, where the seafloor has shifted. This shift could be due to erosion in relation to the contouritic system and/or to the presence of a thrust (Figure 9). The mound is interpreted as a carbonate mound associated with the circulation of water masses and fluid seepage percolating through the fault.

\subsection{The Northern Frontal Deformation of the SAR}

A northward-verging anticline, associated with a blind thrust, characterizes the northern front of deformation of the SAR (Figures 6, 7, and 11b). It presents asymmetric dipping of the forelimb and backlimb. The tip of the blind thrust ends in the Miocene (Figures 6 and 7). Along the deformation front of the SAR, several unconformities are identified in the Plio-Quaternary units (Figures 6, 7, and 11b). From the M to the P0 horizons, no clear variation in thickness is visible, evidence that this deformation front was initiated after P0. Growth strata are observed from the P0 to the P1 horizons on both sides of the deformation front anticline (Figure 11b), pointing to growth of this anticline at this period. On the northern limb of the deformation front, from P1 to Q0 horizons, there is no obvious variation in thickness (Figure 11b). The Q0 reflector represents a major unconformity on which the Q1 and Q2 reflectors progressively onlap, evidence that the deformation front was created during this period (Figure 11b, offset $38-40 \mathrm{~km}$ ).

On the southern limb of the deformation front anticline, growth strata appear between the M reflector and the seafloor, which are interpreted as the result of the uplift of the southernmost structure called the main 


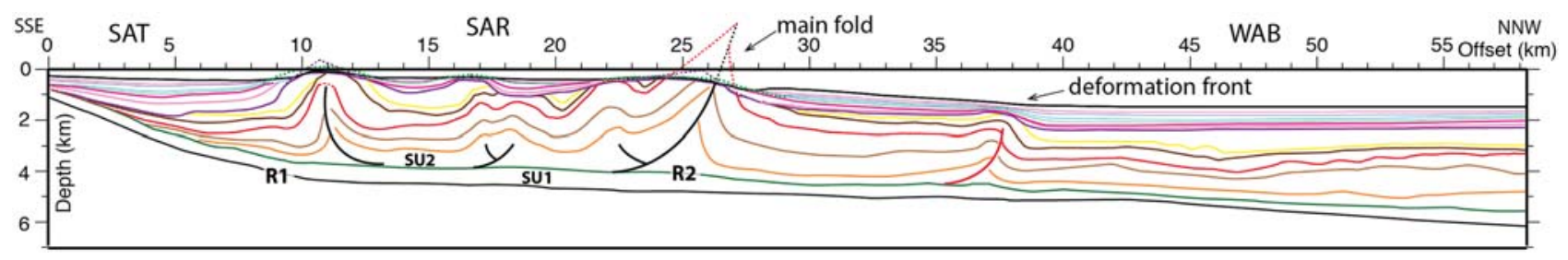

Figure 12. Depth converted horizons of the seismic line CAB121 (1/1 scale) using the interval velocity Vp given in Figure 3. The SAR deformation is shown with no vertical exaggeration SAT $=$ South Alboran Trough; SAR $=$ South Alboran Ridge; WAB $=$ West Alboran Basin.

fold (Figures 6 and 10). The seafloor expression of this front indicates recent deformation (slide scars and sediment instabilities). In addition, in the Plio-Quaternary units and at the seafloor, a series of normal faults and slide scars are exposed above the blind thrust in the hinge of the anticline, related to gravity sliding and extrados deformation.

We conclude that from Q0 to the present day, the deformation front has uplifted with the growth of the anticline related to blind thrusts. Before Q0, the main fold was active and formed the perched piggyback basins (Figures 6 and 7). The local unconformities and variations in thicknesses reveal different phases of acceleration, deceleration, and stopping of compressional phases through the SAR with local folding.

\subsection{The SAR Region}

Line-length restoration analysis of two stages (R5 and BQD) was performed on the CAB121 profile to approximately quantify the horizontal shortening (Figure 12 and Table 1). The seismic section was first converted to depth (Figure 12), and the total reflector length between two reference points was measured at both ends of the profile. The uppermost depositional surface of R5 and BQD was restored to its original prefolding geometry by removing younger strata and restoring the erosional material and deformed strata. The interpreted horizontal shortening amounts to approximately $8.5 \mathrm{~km}$ from the top Serravallian reflector (R5; $\sim 11.6 \mathrm{Ma}$ ), approximately $2.2 \mathrm{~km}$ from the top Messinian (M; 5.33 Ma) and approximately $500 \mathrm{~m}$ from the base of the Quaternary (BQD; 2.6 Ma). Shortening estimates in the cover strata of the SAR fold-and-thrust belt of about $6.3 \mathrm{~km}$ over $6.29 \mathrm{Ma}$ (R5-M reflectors) suggest a shortening rate of about $\sim 1 \mathrm{~mm} / \mathrm{yr}$ during the upper Miocene. Shortening estimates of about $1.7 \mathrm{~km}$ over $2.7 \mathrm{Ma}$ (M-BQD reflectors) suggest a shortening rate of about $0.6 \mathrm{~mm} / \mathrm{yr}$ during the Pliocene. From the quaternary (BQD), the approximate shortening rate reached $0.2 \mathrm{~mm} / \mathrm{yr}$, evidence for a decrease in compressional deformation from the upper Miocene to the present.

These values (Table 1) represent the sum of shortening estimated for three incremental time steps: (1) top Serravallian to the present, (2) Messinian to the present, and (3) base of the Quaternary to the present. These estimates represent the minimum shortening because line-length restorations underestimate the shortening strain, as they do not consider variations in thickness during deformation or oblique deformation with strike-slip components (Martinez-Garcia et al., 2017). The last point is certainly the most important for the measurement of inversion in the Alboran Sea, as most of the shortening is accommodated on inherited structures (normal and strike-slip faults). The values given are therefore minimum estimates with strong approximations.

\section{Discussion}

\subsection{Presence of Weak Layers}

Part of the observed SAR shortening could be linked to the presence of weak layers, such as the well-described overpressure shale levels in the WAB shale province (Figure 1; e.g., Soto et al., 2010). Unlike in the other Mediterranean basins, the Messinian evaporite unit has only occasionally been documented in the Alboran Basin (Estrada et al., 2011), and it is difficult to prove it as a major actor in the decollement processes. Two potential levels of detachment can be proposed in the Alboran Domain. One located at the Ghomaride complex (SU1) and one located in the Langhian unit composed of undercompacted shales (SU2) (Do Couto et al., 2016). The Malaguide-Ghomaride complex, structurally located at the top of the 
Alboran domain, outcrops onshore in the western part of the Betic Cordilleras and at the north of the Rif, at the boundary between the internal and external zones (Vissers et al., 1995). The Ghomaride unit (SU1) is tilted and sealed by the Aquitanian to Langhian unit (SU2) (Figures 6, 8, and 9). The stratigraphic succession of the Ghomaride complex consists of Paleozoic shales and grauwackes from base to top, followed by mainly Mesozoic series containing conglomerates and carbonates and Triassic evaporites, and ending in a Cretaceous sandstone series (Lonergan \& Mange-Rajetzky, 1994; Chalouan et al., 2008). Given its heterogeneous nature and layering, the complex Malaguide-Ghomaride unit (SU1) could act as a detachment layer.

In the El Jebha well, several overpressure levels have been recorded in the Miocene sedimentary sequence above the Ghomaride unit (Morley, 1993; Chalouan et al., 1997; Ammar et al., 2007). The detachment level, which we interpreted as related to the Langhian shales (SU2), dips slightly northward, and all the major thrust faults are interpreted to root on it. Lift-off folds are visible, and the beds and the detachment level are isoclinally folded in the core of the anticline (Mitra \& Namson, 1989) (Figures 6 to 9). The Tofiño Bank anticlines are very tightly folded, strongly eroded at the top, and involve the Miocene units (Figures 6 and 7). The shape of the anticlines indicates that the underlying Langhian shales (SU2) act as an efficient decollement level with ductile behavior. Tight folds have also been described in other regions where weak layers are present (e.g., Northern Borneo; Morley et al., 2003).

Although a decoupling exists between the Ghomaride/Basement (SU1) and the upper sedimentary units, we propose that the undercompacted Langhian shales (SU2) are the main weak layer rather than the Ghomaride/Basement (Figure 12), as a result of its ductile behavior, this unit being overpressured and undercompacted (Fernández-Ibáñez \& Soto, 2017) consistent with the tight geometries of the observed folds.

The pinched anticlines are associated with broad Miocene synclines (Figures 6 and 7), and their shape may depend on the level of erosion above the detachment, as observed by Sherkati et al. (2005). The change in the inclination of the Miocene synclinal and anticlinal axial surfaces reflects the change in depth of the decollement layer SU2 and the presence of a back-thrust fault above the metamorphic basement (Figures 6, 11a, and 12). Such relationships between thickness and depth in the decollement and fold features were described by Suppe et al. (2004). The presence of mobile shale acting as a detachment layer in fold and thrust belts has been observed in other areas such as in the western Gulf of Mexico and the Niger Delta (e.g., Wu \& Bally, 2000).

\subsection{Mechanical Behavior of the Weak Layer Below the SAR}

As mentioned in previous studies (Mauffret et al., 2007; Bourgois et al., 1992; Martinez-Garcia et al., 2017), the Xauen Bank is structured by the same units as those observed in the WAB. This implies that the $5 \mathrm{~km}$ thick Miocene sedimentary layers of the Xauen and Tofiño Banks are related to the subsidence event that started during the Aquitanian in the WAB (Comas et al., 1999) (Figure 10). During the Miocene, the WAB and the SAR formed a single depocenter (West Alboran Mud Province; Figures 5a and 10). A large mud diapir province is observed in the WAB where thick Neogene sediments accumulated (Figure 10) (e.g., Woodside et al., 2000; Comas et al., 2003; Soto et al., 2012). The shale diapirs pierce the upper Miocene and the Plio-Quaternary units, extruding shale units and Miocene breccia to the surface and forming mud volcanoes (e.g., Somoza et al., 2012) (Figure 10).

In contrast to the WAB, mud volcanism is not observed in the SAR region (Figure 10). The SAR shows a series of anticlines that are intruded by chaotic and low-amplitude seismic facies interpreted as mobile shale (Figurs 6, 7,and 9). Shale intrusions were interpreted as occurring at the fold cores and along the E-W striking thrusts (Figures 9 and 10). Thrusts can weaken and facilitate erosion of the fold crest, enabling deep units of undercompacted shales to be brought close to the surface (Figure 6).

The difference in the shale behavior between the WAB and the Xauen-Tofiño Banks area (mud volcanoes vs. mud related to fold and thrust) can be explained by their mechanical behavior. Shale is a plastic material whose strength depends on the magnitude of the pore fluid overpressure (Mourgues et al., 2009). As soon as the mechanism generating pore fluid overpressure changes (disequilibrium compaction, pore space, volume of pore fluid, hydrocarbon generation, and permeable rocks), abnormal pressures may tend to dissipate, and/or fluid can escape from the reservoir (Neuzil, 1986). Overpressures may be transient and vary in space and over time. The shale in the WAB is highly overpressured and undercompacted (Fernández-Ibáñez \& Soto, 2017), and as a result, it becomes mobile and deforms under low stresses, 
rising and producing diapirs and mud volcanoes (e.g., Deville et al., 2006; Somoza et al., 2012). In the SAR region, several tectonic events have affected the Miocene depocenter and generated faults that can either become barriers or preferential conduits. Due to the uplift and resulting erosion since the Tortonian (Figure 5), we propose that the lithostatic pressure is lower in the SAR region than in the much thicker WAB.

Therefore, the SAR is a clear example of interaction between shale and tectonic processes: Shale acts as a decollement level thereby influencing the style of deformation, and the tectonic processes allow the ascent of the shale along thrust faults.

\subsection{The Style of Deformation of the SAR}

In a context of convergence, compressional deformation observed in continental margins and basins can be explained either by thick and thin-skinned tectonics or by deep water fold and thrust belt processes in a high sedimentation rate margin associated to gravitational processes. Which of these mechanisms are involved during the different stages of basin evolution in the southern part of the Alboran Sea is not yet clear. The SAR developed over an inherited Miocene depocenter in the continuity of the WAB (Figures 5 and 10). The SAR appears to be structured mostly by folds related to thrust faults. At depth, we propose that the thrusts root into the Langhian shale (SU2) considered as a decollement layer above the Ghomaride unit (SU1; Figure 12). The top basement corresponds to the northward dipping R1 reflector from the Moroccan margin, followed by a flattening of R1 from the SAT toward the north (Figures 6, 8, and 12).

The deformation observed throughout the SAR region can be compared to the end members of the thin-skinned and thick-skinned tectonic model described in mountain ranges (e.g., Pfiffner, 2017). In the case of thick-skinned tectonics, deformations through the crust and possibly the lithospheric mantle are involved. In the case of thin-skinned tectonics, the style of folding and thrusting is controlled by the thickness of a decollement layer as well as by the mechanical contrast between the decollement layer and the sedimentary cover (e.g., Pfiffner, 2017).

The deformation recorded in the thin-skinned case resembles that observed in deep water fold and thrust belts, although their tectonic setting differs significantly )Morley, 2009). Deep water fold and thrust belts appear where rapid sedimentation and overpressured mobile shales can occur and initiate a decollement layer that is not necessarily located at the top of the crystalline basement (e.g., Morley, 2009). The deep-water fold and thrust belts are associated with large-scale gravitational failure of submarine slopes (Rowan et al., 2004) and present extensional structures in proximal areas and compressive structures in distal areas (e.g., Rowan et al., 2004). In the Moroccan offshore margin, in contrast to the Spanish margin (Soto et al., 2010), postrift extensional structures such as normal faults are not observed. The offshore Moroccan margin and the Miocene and Plio-Quaternary units pinch out onto the tilted Ghomaride unit (SU1) without normal Plio-Quaternary faulting (Figures 6 to 8). The lack of extensional deformation in the sedimentary cover in the proximal domain is not consistent with large-scale gravity-driven deformation associated with deep water fold and thrust belts as well as thin-skinned tectonics. Proximal extensional structures do not need to be present if (i) the structures are eroded, (ii) located in the onshore zone, or (iii) if we consider a large-scale mass sliding process with a decollement parallel to the horizon (R2).

Onshore Morocco, the Pliocene basins suffered only N-S normal faulting (Romagny et al., 2014), which cannot be associated with the contractional fold belts. The lack of shallow extensional structures could rather be interpreted as a result of thick-skinned tectonics with deep-rooted, basement-related tectonics to accommodate shortening. In a case of basin inversion, horizontal contraction leads to the reactivation of well-oriented preexisting normal faults and/or strike-slip faults that can lead to localized uplift and the involvement of basement tectonics. The preexisting normal extension and major shear zone related to the westward Alboran domain migration were able to localize the deformation at a crustal scale (Figures 13a and 13b). The exact nature and geometry of structures involving basement rocks was not detected due to the lack of deep data. However, in the Alboran Ridge, the positive flower structure observed in seismic reflection data testifies to an episode of intense crustal shear that can be related to the STEP fault event (Figure 13b). An equal amount of shortening would need to be recorded in the basement and in the sedimentary cover at crustal scale. Basement shortening could be accommodated by deep ductile distributed deformation or by crustal 

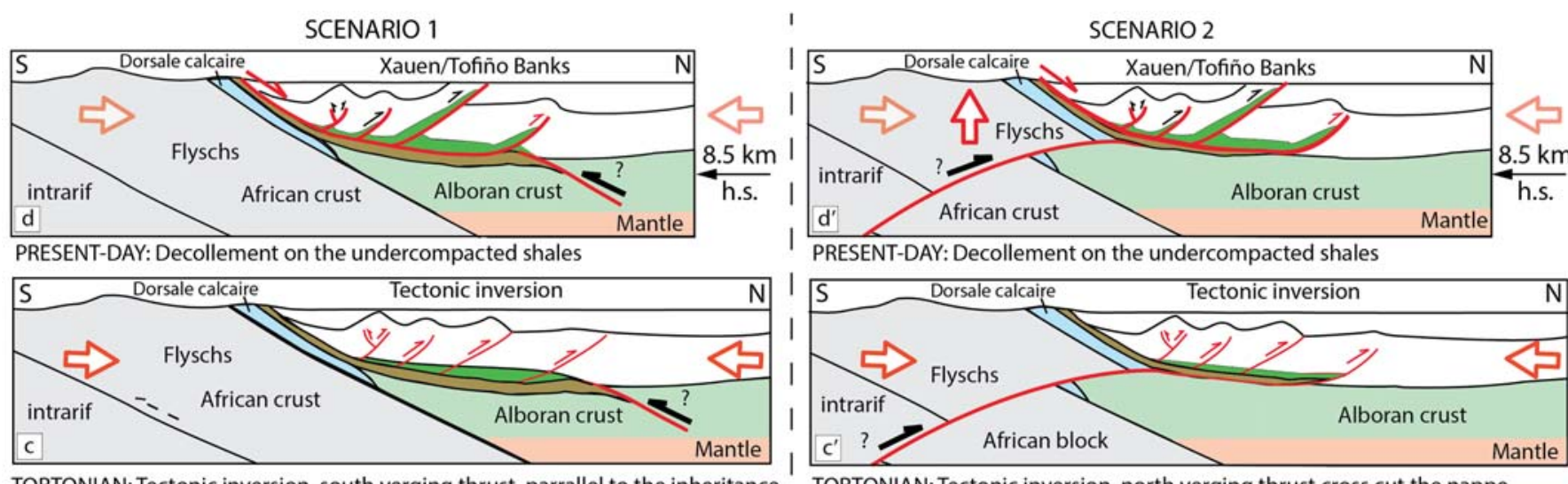

TORTONIAN: Tectonic inversion, south verging thrust parrallel to the inheritance

TORTONIAN: Tectonic inversion, north verging thrust cross cut the nappe

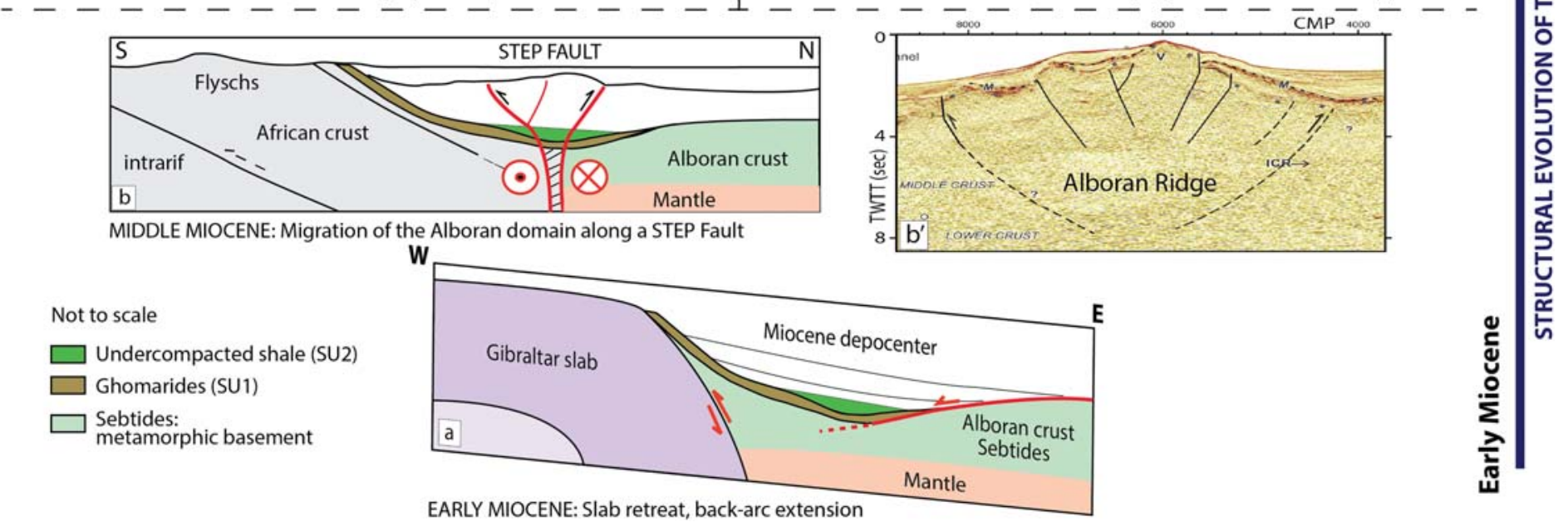

Figure 13. Cross-section sketch of the structural evolution of the southern Alboran Sea from the Early Miocene to the present. (a) Slab retreat and back-arc Early Miocene extension. Note the different orientation of this W-E cross section. (b) Middle Miocene migration of the Alboran block along the STEP fault. (b') Seismic reflection profile through the Alboran Ridge modified from Gomez de la Peña et al. (2018) showing a positive flower structure. Two scenarios are discussed. (Scenario 1) (c,d) South verging parallel to the inheritance hypothesis. (Scenario 2) ( $\mathrm{c}^{\prime}, \mathrm{d}^{\prime}$ ) North verging parallel to the inheritance hypothesis. $\left(\mathrm{c}, \mathrm{c}^{\prime}\right)$ Tortonian tectonic inversion with shortening. $\left(\mathrm{d}, \mathrm{d}^{\prime}\right)$ Present-day Xauen-Tofiño banks deformation. h.s. = horizontal shortening from this study (Table 1). Not to scale.

thrusting. To accommodate the recorded shortening at the basement scale, without considering a distributed ductile deformation, we propose two hypotheses: a north or south verging thrust (Figures 13c, 13d, 13c', and $13 \mathrm{~d}^{\prime}$ ). The south verging thrust is parallel to the imbricated Intrarif inherited nappes (Figures 13c and 13d). The north verging thrust crosscutting the nappes (Figures $13 \mathrm{c}^{\prime}$ and $13 \mathrm{~d}^{\prime}$ ) is consistent with the present-day vergence of the tectonic indentation of the African block into the Alboran block (Estrada et al., 2018) and with the present-day uplift of the Moroccan margin (Poujol et al., 2014). Because the basement faults in the Alboran Sea are difficult to image, their existence, timing, and precise role in the deformation are very difficult to assess.

Finally, we propose that thick-skinned and thin-skinned tectonics both occur here as observed in most of the orogens (Pfiffner, 2017). To accommodate the shortening, the most favorable geometry of the thick-skinned tectonics hypothesis is a north verging crustal thrust. The present-day relative contribution of thin-skinned and/or thick-skinned tectonics versus gravity-driven folding cannot be clearly assessed. However, given that (i) the SAR structures developed at the foot of the steep uplifted Moroccan margin (Figures 10 and 12), (ii) the frontal deformation shows sign of recent activity with no important associated seismicity (Figure 10), and (iii) Miocene shale intrusions seem to occur along the thrust faults, one reasonable outcome is that part of the recent deformation was caused by large northward gravitational spreading over the undercompacted shale units. 


\subsection{Tectonic Inversion in the SAR Region}

The SAR region represents the eastern continuity of the WAB Miocene depocenter that has been inverted (Figure 5). At the Alboran Sea scale, tectonic inversion occurred from the late Tortonian on (e.g., Martinez-Garcia et al., 2017; Do Couto et al., 2016). This inversion varies in space and over time, but most of the inversion is concentrated along the Alboran Ridge (Martinez-Garcia et al., 2017) and the SAR (this study) and has been ongoing since the Tortonian.

The values of the horizontal shortening we obtained agree with those obtained by previous authors with a decrease of the sum of shortening values from the Tortonian to the Quaternary (Table 1). Shortening was then estimated by Flecker et al. (2015) to be around 10 to $15 \mathrm{~km}$ from the Moroccan marine gateways in the late Miocene before the Messinian salinity crisis. Ammar et al. (2007) proposed an estimated shortening of $3.5 \mathrm{~km}$ from the Messinian along the Xauen Bank. Martinez-Garcia et al. (2017) estimated a shortening from $~ 3$. Ma reaching maximum values up to $2 \mathrm{~km}$ in the central Alboran Ridge and decreasing to 1$1.5 \mathrm{~km}$ to the northeast and the southeast. As in our study, these results correspond to a shortening rate of about $\sim 0.6 \mathrm{~mm} / \mathrm{yr}$ since $3.3 \mathrm{Ma}$ (P1). The estimates of shortening are therefore similar in the SAR and in the Alboran Ridge for the Pliocene epoch. Because there is no undercompacted shale in the Alboran Ridge area that can act as a shallow decollement layer, similar shortening rates indicate that the main shortening mechanism along the SAR is more likely a thick-skinned than a thin-skinned tectonic process.

In relation to the direction of convergence, the E-W Miocene depocenter of the SAR located in the southern part of the West Alboran Basin is better oriented for an inversion process than the main WAB N-S depocenter (Figure 14c). DeMets et al. (2015) precisely reconstructed the rotation poles between Eurasia and Africa during the Neogene and Quaternary. These authors show a constant N135 ${ }^{\circ}$ direction of Africa-Eurasia convergence from $\sim 7 \mathrm{Ma}$ to the present. The predicted interval slip directions are too small and/or too short lived to conclude that a significant change in direction has occurred since $20 \mathrm{Ma}$ (DeMets et al., 2015). Moreover, this high-resolution reconstruction study predicts that Nubia-Eurasia motion has also been relatively steady during the past $\sim 13 \mathrm{Myr}$, ranging from $4 \mathrm{~mm} / \mathrm{yr}$ near the Azores Triple Junction to $7 \mathrm{~mm} / \mathrm{yr}$ in the central Mediterranean. The SAR region has accommodated a significant part of this constant convergent motion with a total shortening rate of around $1 \mathrm{~mm} / \mathrm{yr}$, which has decreased since the Tortonian. The remaining $4 \mathrm{~mm} / \mathrm{yr}$ should be accommodated (i) along the main strike-slip fault, (ii) as a vertical uplift, and (iii) mostly onshore (e.g., Table 1). The overall shortening recorded in the Rif led to the frontal emplacement of the Prerif nappes over the African foreland (e.g., Chalouan et al., 2008; Michard et al., 2006; Capella et al., 2017). Recent contractional onshore deformation is observed and is still active (Bargach et al., 2004; Koulali et al., 2011).

In the southern part of the Alboran Sea, the style of deformation and the width of the deformed area (i.e., increases in the number of folds) vary from the Alboran Ridge in the east to the SAR in the west (Figure 1). This is most probably due to the presence or absence of a decollement layer of undercompacted shale and of magmatic bodies. In the central basin and hence through the Alboran Ridge, the metamorphic basement has been affected by Neogene magmatic arc activity (Figure 1; e.g., Duggen et al., 2004; Booth-Rea et al., 2018; Gómez de la Peña et al., 2018). The presence of these magmatic bodies may also have influenced the different deformation styles observed between the SAR and the Alboran Ridge.

Moreover, the large obliquity between the direction of the E-W Miocene shale depocenter of the SAR and the relatively steady $\mathrm{N} 135^{\circ}$ direction of convergence from 13 Ma contributes to the present-day SAR structural pattern (DeMets et al., 2015).

\subsection{Structural Evolution of the Xauen-Tofiño Banks}

The structure of the SAR results from a four-step evolution involving a series of deformation steps including extensional, shearing, and contractional processes (Figures 13 and 14).

The first step was linked to the western migration of the Alboran Domain with the Gibraltar slab retreat (Figures 13a and 14a) (Do Couto et al., 2016). The contact between the metamorphic basement and the Ghomaride nappes was documented onshore as an extensional shear zone (e.g., Lonergan \& Platt, 1995; Crespo-Blanc, 1995; Augier et al., 2005), which acted through a N-S to NNE-SSW stretching direction from 22 to $18 \mathrm{Ma}$ (e.g., Crespo-Blanc, 1995; Platt et al., 2005). Offshore Morocco, the base of the Ghomaride unit 


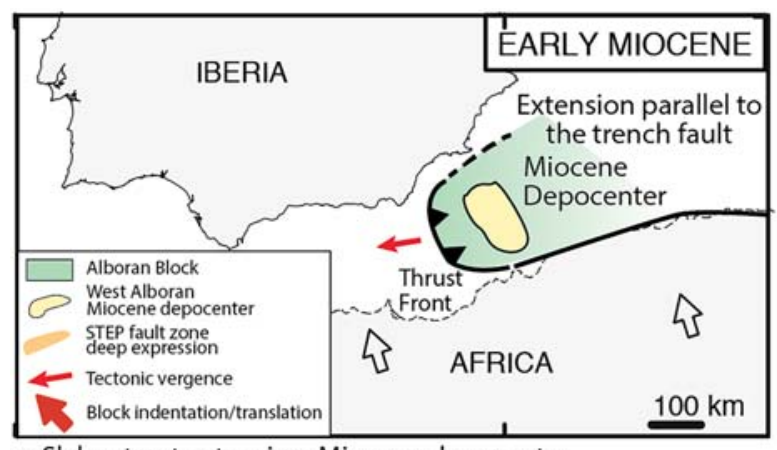

a. Slab retreat extension: Miocene depocenter

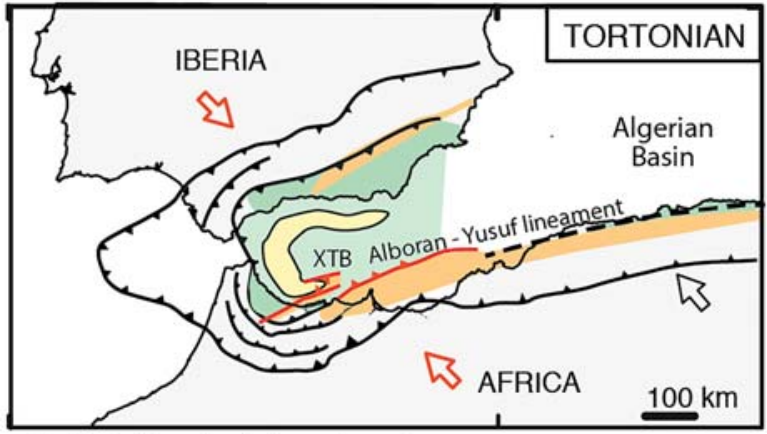

c. End of slab retreat: inversion stage

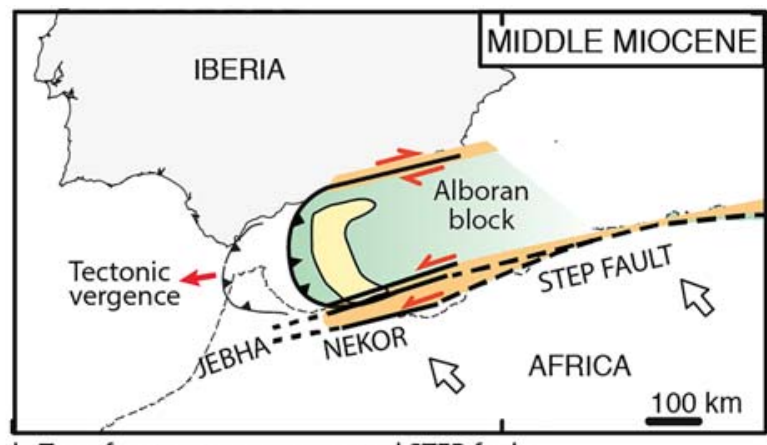

b. Transfer structure: segmented STEP fault

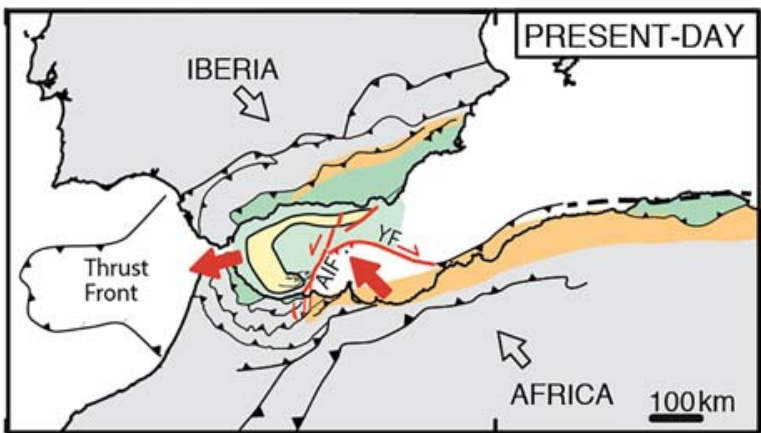

d. Tectonic indentation of the Africa into Betico-Rifian block

Figure 14. Sketch maps of the structural evolution of the Alboran Sea from the Early Miocene (a) to the present (d). Red arrow $=$ active structure. A current westward translation is indicated by GPS data (e.g., Koulali et al., 2016). The location of the West Alboran Basin, of the internal zone, and of the STEP fault and the structural features are from Leprêtre et al. (2013), Spakman and Wortel (2004), Bezada et al. (2013), Jabaloy-Sanchez et al. (2015), Mancilla et al. (2015), Do Couto et al. (2016), Estrada et al. (2018), and Hidas et al. (2019). XTB = Xauen-Tofiño Banks; AIF = Al Idrissi fault zone; YF = Yusuf fault.

(SU1) is also proposed to act as a detachment fault during the late Oligocene-early Miocene (Chalouan et al., 1995; Do Couto et al., 2016). At this step, the WAB formed in the east and migrated westward (Do Couto et al., 2016). We propose that the WAB extended farther southeastward than previously thought and constitutes the synrift SU2-SU3 lower Miocene depocenter of the SAR. Langhian undercompacted shales are present at the base of this depocenter (Figure 4).

The second step in the development of the SAR is related to the occurrence of vertical lithospheric tears (STEP fault) deduced from geophysical and field studies (Figures 13b and 14b). Under the central Betics to the north and under Morocco to the south, a sharp lithospheric and crustal step can be recognized in the receiver function computations, tomographic images, and gravimetric data (e.g., Spakman \& Wortel, 2004; Bezada et al., 2013; Levander et al., 2014; Mancilla et al., 2015; Petit et al., 2015; Diaz et al., 2016; Molina-Aguilera et al., 2019) In northern Morocco in particular, a sharp change in crustal thickness is visible at the city of $\mathrm{Al}$ Hoceima, where the crust is more than $40 \mathrm{~km}$ thick to the west but less than $30 \mathrm{~km}$ thick to the east (Diaz et al., 2016). These abrupt offsets are interpreted as the termination of the Iberian and Nubia lithosphere caused by a vertical STEP fault (e.g., Spakman \& Wortel, 2004; Levander et al., 2014; Mancilla et al., 2018; Hidas et al., 2019). These lithospheric STEP faults along the North African margins and along the Balearic margin accommodate the westward migration of the Gibraltar slab (e.g., Spakman \& Wortel, 2004). Subvertical lithospheric-scale tear faults are thought to have accommodated approximately $270 \mathrm{~km}$ of roll-back movement (Spakman et al., 2018), and most of this offset occurred between 20 and 7 Ma (Faccenna et al., 2004; Pérez-Valera et al., 2013; Spakman et al., 2018). The age of tearing has been determined in the Betic side using volcanic intrusions in the strike-slip faults (Pérez-Valera et al., 2013). These authors determined older ages (9.3-8.2 Ma) in the eastern part of the Betics and younger ages (7.3-7.1 $\mathrm{Ma})$ in the western part compatible with the westward retreat of the lithospheric slab beneath the eastern Betics.

Surface expressions of the inherited STEP faults in the southern Alboran block can be observed onshore and offshore. Onshore Morocco, two major NE-trending transfer faults related to the westward migration of the 
internal domain were recognized, the Jebha-Chrafate and the Nekor faults (Leblanc, 1980; Frizon de Lamotte, 1985; Benmakhlouf et al., 2012; Vitale et al., 2014; Azdimousa et al., 2019). Their sinistral activity began in the Oligocene (Figures 13b and 14b) (Benmakhlouf et al., 2012; Achalhi et al., 2016). An offshore crustal structure analysis shows that the Alboran Ridge and the Yusuf fault limit the North African continental crust to the south from the Alboran continental block to the north (e.g., Gómez de la Peña et al., 2018). The Gibraltar slab retreat may have been accommodated by a broad shear zone represented by the onshore Jebha and Nekor transfer faults and by the offshore Alboran Ridge, SAR, and Yusuf fault (Figure 14b). Seismic reflection data crossing the Alboran Ridge show a positive flower structure in agreement with the presence of a major inherited shear zone (Figure 13b'). The present expression of this shear zone is considered as a STEP fault located in sharp contrast to the crustal thickness between the Africa and Alboran block (e.g., Mancilla et al., 2015; Badji et al., 2015; Diaz et al., 2016).

The third step records the beginning of the tectonic inversion through the Alboran basin (Figures 13c and 14c). Once the westward retreat of the Gibraltar slab decreased and finally stopped, the roughly NW-SE continuous convergence between Africa and Iberia became the predominant process, and the Alboran basin inversion began. This inversion, related to the final dying of the subduction zone at the Gibraltar area, is recorded with the collision of the thrust sheet pile of the internal domain against the external domain (Ziegler et al., 1998; Chalouan et al., 2008; Vitale et al., 2015; Capella et al., 2017;). The Jebha-Chrafate transfer fault was inverted and reactivated during the Late Miocene (Benmakhlouf et al., 2012). In the SAR region, the WAB inversion produced the structural style composed of fold and thrust systems (Figures 13c and 14c); this inversion began at the end of the Tortonian and is characterized by different pulses.

The last step corresponds to the reorganization of the plate boundary between Nubia and Iberia. Pleistocene initiation of the Al Idrissi fault zone (Lafosse et al., 2018) marks the onset of the present-day plate boundary. The tectonic indentation of the African plate into the Alboran domain led to the nucleation of the Al Idrissi strike-slip fault [Estrada et al., 2018; Figure 14d). The tearing of the slab and hence the location of the present-day STEP fault propagated under the external domains (e.g., Mancilla et al., 2015). The North African plate overrides the Alboran domain leading to the present-day surface expression of the STEP fault (Alboran Ridge, Yusuf fault, and Jebha and Nekor faults) that does not coincide with the present-day deep structure (Figure 14d). The actual boundaries of the slab tear are determined by mapping the missing orogenic root under the Betics and Rif (e.g., Mancilla et al., 2015; Hidas et al., 2019). The convergence motion is oblique to the E-W striking folds and major conjugate fault sets causing the reactivation and rotation of the Miocene SAR-Alboran Ridge and Yusuf fault (Figure 14d).

\section{Conclusions}

Four main stages of deformation have been recognized in the SAR region. (1) The Early Miocene extension occurred with syntectonic wedges related to normal faulting, as already observed in the North Alboran Ridge (Martinez-Garcia et al., 2013, 2017). The SAR region is interpreted as the continuity of the very thick Miocene West Alboran depocenter related to the West Alboran mud province. (2) The southern part of the WAB depocenter was deformed by the activity of a STEP fault related to the Gibraltar slab retreat. (3) When the Gibraltar slab retreat decreased and finally stopped, the basin subsequently inverted. We thus interpret the SAR zone to have been formed by contractional overprinting of the shear zone. (4) The oblique convergence and the tectonic indentation of the Africa into the Betico-Rifian Block lead to the nucleation of the Al Idrissi fault zone.

The present-day SAR region is dominated by E-W trending folds and thrusts with evidence of active compressional deformation from the Late Miocene to the present. An acceleration in the uplift and compressional activity is evidenced at the end of the Miocene. The structural style of the fold and thrust suggests a weak decollement layer corresponding to overpressured shale but could also reflect the existence of an intracrustal fault. The Tortonian inversion and associated gravity-driven movement, superimposed on the Africa indentation, induced the present-day style of deformation of the SAR. The present-day structure of back-arc basins reflects the structural impact of different major events that the basin has undergone since its initial stage of thinning. Our study enabled us to understand the tectonic and sedimentary processes responsible for the structure we now observe in reactivated back-arc basins. We show that weak layers and inherited crustal structures play a major role in the style and mode of deformation of the fore-arc basins. In 


\section{Acknowledgments}

We thank the members of the SARAS and Marlboro cruises in 2011 and 2012. This work was funded by the French program Actions Marges, the ALBAMAR JCJC ANR-17-CE03-0004, the EUROFLEETS program (FP7/ 2007-2013; 228344), and project FICTS-2011-03-01. We thank Serge Lallemand, Tim Minshull, and an anonymous reviewer for the useful comments and suggestions. Seismic reflection data were processed using the Seismic UNIX SU and Geovecteur( software. The processed seismic data were interpreted using Kingdom IHS Suite $\odot$ software. This work also benefited from the DAMAGE (AEI/FEDER CGL2016-80687-R) and Fauces (Ref CTM2015-65461-C2-R; MINCIU/FEDER) Projects financed by "Ministerio de Economía y Competitividad y al Fondo Europeo de Desarrollo Regional" (FEDER). Seismic reflection and bathymetric data collected during the MARLBORO and SARAS cruises are stored at SISMER and Seanoe (SEA scieNtific Open data Edition) (https://doi.org/10.17600/ 11480100, https://doi.org/10.17600/ 12450090, and https://campagnes.flotteoceanographique.fr/campagnes/ 12000010). particular, the major tectonic imprint of the STEP faults that accommodate the slab-roll back is highlighted as is the sedimentary imprint of the undercompacted shale that may act as a decollement layer. Understanding the deformation processes around the tip of back-arc basins will provide key information on the forces and dynamics controlling the inversion of step faults on the edge of subduction areas. Wide-angle seismic studies are necessary to elucidate the presence and geometry of the deep crustal structure like the STEP fault and intracrustal thrusts.

\section{References}

Achalhi, M., Münch, P., Cornée, J.-J., Azdimousa, A., Melinte-Dobrinescu, M., Quillévéré, F., et al. (2016). The late Miocene Mediterranean-Atlantic connections through the North Rifian Corridor: New insights from the Boudinar and Arbaa Taourirt basins (northeastern Rif, Morocco). Palaeogeography, Palaeoclimatology, Palaeoecology, 459, 131-152. https://doi.org/10.1016/j. palaeo.2016.06.040

Afiri, A., Gueydan, F., Pitra, P., Essaifi, A., \& Précigout, J. (2011). Oligo-Miocene exhumation of the Beni-Bousera peridotite through a lithosphere-scale extensional shear zone. Geodinamica Acta, 24(1), 49-60. https://doi.org/10.3166/ga.24.49-60

Ammar, A., Mauffret, A., Gorini, C., \& Jabour, H. (2007). The tectonic structure of the Alboran Margin of Morocco. Revista de La Sociedad Geológica de España, 20(3-4), 247-271.

Argnani, A. (2014). Comment on the article "Propagation of a lithospheric tear fault (STEP) through the western boundary of the Calabrian accretionary wedge offshore eastern Sicily (Southern Italy)” by Gallais et al., 2013. Tectonophysics, 610, 195-199.

Armentrout, J. M., Malecek, S. J., Braithwaite, P., \& Beeman, C. R. (1991). Seismic facies of slope basin turbidite reservoirs, East Breaks 160-161 Field: Pliocene-Pleistocene, Northwestern Gulf of Mexico. In P. Weimer, \& M. H. Link (Eds.), Seismic facies and sedimentary processes of submarine fans and turbidite systems, (pp. 223-239). New York, NY: Springer New York. https://doi.org/10.1007/ 978-1-4684-8276-8_11

Augier, R., Agard, P., Monié, P., Jolivet, L., Robin, C., \& Booth-Rea, G. (2005). Exhumation, doming and slab retreat in the Betic Cordillera (SE Spain): In situ ${ }^{40} \mathrm{Ar} /{ }^{39} \mathrm{Ar}$ ages and P-T-d-t paths for the Nevado-Filabride complex. J. Metamorphic Geol., 23, 357-381.

Azdimousa, A., Jabaloy-Sánchez, A., Münch, P., Martínez-Martínez, J. M., Booth-Rea, G., Vázquez-Vílchez, M., et al. (2019). Structure and exhumation of the Cap des Trois Fourches basement rocks (Eastern Rif, Morocco). Journal of African Earth Sciences, 150, 657-672. https://doi.org/10.1016/j.jafrearsci.2018.09.018

Badji, R., Charvis, P., Bracene, R., Galve, A., Badsi, M., Ribodetti, A., et al. (2015). Geophysical evidence for a transform margin offshore Western Algeria: A witness of a subduction-transform edge propagator? Geophysical Journal International, 200(2), 1029-1045. https://doi.org/10.1093/gii/ggu454

Ballesteros, M., Rivera, J., Munoz, A., Munoz-Martin, A., Acosta, J., Carbo, A., \& Uchupi, E. (2008). Alboran Basin, southern Spain-Part II Neogene tectonic implications for the orogenic float model. Marine and Petroleum Geology, 25(1), 75-101.

Barcos, L., Balanya, J. C., Diaz-Azpiroz, M., Exposito, I., \& Jimenez-Bonilla, A. (2015). Kinematics of the Torcal Shear Zone: Transpressional tectonics in a salient-recess transition at the northern Gibraltar Arc. Tectonophysics, 663, 62-77.

Bargach, K., Ruano, P., Chabli, A., Galindo-Zaldivar, J., Chalouan, A., Jabaloy, A., et al. (2004). Recent tectonic deformations and stresses in the frontal part of the Rif Cordillera and the Saïss Basin (Fes and Rabat Regions, Morocco). Pure and Applied Geophysics, 161(3), 521-540. https://doi.org/10.1007/s00024-003-2461-6

Benmakhlouf, M., Galindo-Zaldívar, J., Chalouan, A., Sanz de Galdeano, C., Ahmamou, M., \& López-Garrido, A. C. (2012). Inversion of transfer faults: The Jebha-Chrafate fault (Rif, Morocco). Journal of African Earth Sciences, 73-74, 33-43. https://doi.org/10.1016/j. jafrearsci.2012.07.003

Bezada, M. J., Humphreys, E. D., Toomey, D. R., Harnafi, M., Dávila, J. M., \& Gallart, J. (2013). Evidence for slab rollback in westernmost Mediterranean from improved upper mantle imaging. Earth and Planetary Science Letters, 368, 51-60. https://doi.org/10.1016/j. epsl.2013.02.024

Billi, A., Faccenna, C., Bellier, O., Minelli, L., Neri, G., Piromallo, C., et al. (2011). Recent tectonic reorganization of the Nubia-Eurasia convergent boundary heading for the closure of the western Mediterranean. Bulletin de La Societe Geologique de France, 182(4), 279-303. https://doi.org/10.2113/gssgfbull.182.4.279

Booth-Rea, G., Jabaloy-Sánchez, A., Azdimousa, A., Asebriy, L., Vílchez, M. V., \& Martínez-Martínez, J. M. (2012). Upper-crustal extension during oblique collision: the Temsamane extensional detachment (eastern Rif, Morocco): The Temsamane extensional detachment (eastern Rif, Morocco). Terra Nova, 24(6), 505-512. https://doi.org/10.1111/j.1365-3121.2012.01089.x

Booth-Rea, G., Martinez-Martinez, J. M., \& Giaconia, F. (2015). Continental subduction, intracrustal shortening, and coeval upper-crustal extension: P-T evolution of subducted south Iberian paleomargin metapelites (Betics, SE Spain). Tectonophysics, 663, 122-139.

Booth-Rea, G., Ranero, R., \& C., \& Grevemeyer, I. (2018). The Alboran volcanic-arc modulated the Messinian faunal exchange and salinity crisis. Scientific Reports, 8(1), 1-14. https://doi.org/10.1038/s41598-018-31307-7

Bouillin, J. P., Durand-Delga, M., \& Olivier, P. (1986). Betic, Rifian and Tyrrhenian arcs: Distinctive features, genesis and development stage. In F. C. Wezel (Ed.), The origin of arcs, (pp. 281-304). New York: Elsevier.

Bourgois, J., Mauffret, A., Ammar, A., \& Demnati, A. (1992). Multichannel seismic data imaging of inversion tectonics of the Alboran Ridge (Western Mediterranean Sea). Geo-Marine Letters, 12(2-3), 117-122.

Burg, J.-P., \& Ford, M. (1997). Orogeny through time: An overview. Geological Society, London, Special Publications, 121(1), 1-17. https://doi.org/10.1144/GSL.SP.1997.121.01.01

Calvert, A., Sandvol, E., Seber, D., Barazangi, M., Roecker, S., Mourabit, T., et al. (2000). Geodynamic evolntion of the lithosphere and upper mantle beneath the Alboran region of the western Mediterranean: Constraints from travel time tomography. Journal of Geophysical Research, 105(B5), 10871-10898. https://doi.org/10.1029/2000JB900024

Capella, W., Matenco, L., Dmitrieva, E., Roest, W. M. J., Hessels, S., Hssain, M., et al. (2017). Thick-skinned tectonics closing the Rifian Corridor. Tectonophysics, 710-711, 249-265. https://doi.org/10.1016/j.tecto.2016.09.028

Chalouan, A., \& Michard, A. (2004). The Alpine Rif Belt (Morocco): A case of mountain building in a subduction-subduction-transform fault triple junction. Pure and Applied Geophysics, 161(3), 489-519. https://doi.org/10.1007/s00024-003-2460-7 
Chalouan, A., Michard, A., Kadiri, K., Negro, F., Lamotte, D., Soto, J. I., \& Saddiqi, O. (2008). The Rif Belt, In A. Michard, O. Saddiqi, A. Chalouan, \& D. Lamotte (Eds.), Continental evolution: The geology of Morocco (Vol. 116, pp. 203-302), (). Berlin/Heidelberg: Springer. https://doi.org/10.1007/978-3-540-77076-3_5

Chalouan, A., Ouazani-Touhami, A., Mouhir, L., Saji, R., \& Benmakhlouf, M. (1995). Les failles normales à faible pendage du Rif interne (Maroc) et leur effet sur l'amincissement crustal du domaine d'Alboran. Geogaceta, 17, 107-109.

Chalouan, A., Saji, R., Michard, A., \& Bally, A. W. (1997). Neogene tectonic evolution of the southwestern Alboran basin as inferred from seismic data off Morocco. Aapg Bulletin-American Association of Petroleum Geologists, 81(7), 1161-1184.

Chertova, M. V., Spakman, W., Geenen, T., van den Berg, A. P., \& van Hinsbergen, D. J. J. (2014). Underpinning tectonic reconstructions of the western Mediterranean region with dynamic slab evolution from 3-D numerical modeling: Western Mediterranean slab evolution. Journal of Geophysical Research: Solid Earth., 119(7), 5876-5902. https://doi.org/10.1002/2014JB011150

Cloetingh, S., Burov, E., Matenco, L., Beekman, F., Roure, F., \& Ziegler, P. A. (2013). The Moho in extensional tectonic settings: Insights from thermo-mechanical models. Tectonophysics, 609, 558-604. https://doi.org/10.1016/j.tecto.2013.06.010

Comas, M., Zahn, R., \& Klaus, A. (1996). Mediterranean Sea II. Oceanographic Literature Review, 10(43), 999.

Comas, M. C., García-Dueñas, V., \& Jurado, M. J. (1992). Neogene tectonic evolution of the Alboran Sea from MCS data. Geo-Marine Letters, 12(2-3), 157-164.

Comas, M. C., Platt, J. P., Soto, J. I., \& Watts, A. B. (1999). The origin and Tectonic History of the Alboran Basin: Insights from Leg 161 Results. Proceedings of the Ocean Drilling Program Scientific Results, 161, 555-580.

Comas, M. C., Soto, J. I., Talukder, A. R., Marani, M., Akhmanov, G., \& Suzyumov, A. (2003). Discovering active mud volcanoes in the Alboran Sea, western Mediterranean. Geological and Biological Processes at Deep-Sea European Margins and Oceanic Basins, 14-16.

Crespo-Blanc, A. (1995). Interference pattern of extensional fault systems: A case study of the Miocene rifting of the Alboran basement (North of Sierra Nevada, Betic Chain). Journal of Structural Geology, 17(11), 1559-1569.

Crespo-Blanc, A., \& Frizon de Lamotte, D. (2006). Structural evolution of the external zones derived from the Flysch trough and the South Iberian and Maghrebian paleomargins around the Gibraltar arc: A comparative study. Bulletin De La Societe Geologique De France, 177(5), 267-282.

d'Acremont, E., Gutscher, M.-A., Rabaute, A., Mercier de Lépinay, B., Lafosse, M., Poort, J., et al. (2014). High-resolution imagery of active faulting offshore Al Hoceima, Northern Morocco. Tectonophysics, 632, 160-166. https://doi.org/10.1016/j.tecto.2014.06.008

DeMets, C., Iaffaldano, G., \& Merkouriev, S. (2015). High-resolution Neogene and Quaternary estimates of Nubia-Eurasia-North America Plate motion. Geophysical Journal International, 203(1), 416-427. https://doi.org/10.1093/gii/ggv277

Deville, E., Guerlais, S.-H., Callec, Y., Griboulard, R., Huyghe, P., Lallemant, S., et al. (2006). Liquefied vs stratified sediment mobilization processes: Insight from the South of the Barbados accretionary prism. Tectonophysics, 428(1-4), 33-47. https://doi.org/10.1016/j. tecto.2006.08.011

Dewey, J. F. (1988). Lithospheric stress, deformation, and tectonic cycles: The disruption of Pangaea and the closure of Tethys. In M. G. Audley-Charles, \& A. Hallam (Eds.), Gondwanna and Tethys, (Vol. 37, pp. 23-40). London: Geological Society Special Publication.

Dewey, J. F. (2002). Transtension in arcs and orogens. International Geology Review, 44(5), 402-439. https://doi.org/10.2747/ 0020-6814.44.5.402

Diaz, J., Gallart, J., \& Carbonell, R. (2016). Moho topography beneath the Iberian-Western Mediterranean region mapped from controlled-source and natural seismicity surveys. Tectonophysics, 692, 74-85. https://doi.org/10.1016/j.tecto.2016.08.023

Do Couto, D., Gorini, C., Jolivet, L., Lebret, N., Augier, R., Gumiaux, C., et al. (2016). Tectonic and stratigraphic evolution of the Western Alboran Sea Basin in the last 25 Myrs. Tectonophysics, 677, 280-311.

Do Couto, D., Gumiaux, C., Augier, R., Lebret, N., Folcher, N., Jouannic, G., et al. (2014). Tectonic inversion of an asymmetric graben: Insights from a combined field and gravity survey in the Sorbas basin. Tectonics, 33(7), 2013TC003458. https://doi.org/10.1002/ 2013 TC003458

Duggen, S., Hoernle, K., van den Bogaard, P., \& Harris, C. (2004). Magmatic evolution of the Alboran region: The role of subduction in forming the western Mediterranean and causing the Messinian Salinity Crisis. Earth and Planetary Science Letters, 218(1), 91-108. https://doi.org/10.1016/S0012-821X(03)00632-0

Ercilla, G., Juan, C., Hernandez-Molina, F. J., Bruno, M., Estrada, F., Alonso, B., et al. (2016). Significance of bottom currents in deep-sea morphodynamics: An example from the Alboran Sea. Marine Geology, 378, 157-170. https://doi.org/10.1016/j.margeo.2015.09.007

Ercilla, G., Juan, C., Periáñez, R., Alonso, B., Abril, J. M., Estrada, F., et al. (2019). Influence of alongslope processes on modern turbidite systems and canyons in the Alboran Sea (southwestern Mediterranean). Deep Sea Research Part I: Oceanographic Research Papers, 144, 1-16. https://doi.org/10.1016/j.dsr.2018.12.002

Estrada, F., Ercilla, G., Gorini, C., Alonso, B., Vazquez, J. T., Garcia-Castellanos, D., et al. (2011). Impact of pulsed Atlantic water inflow into the Alboran Basin at the time of the Zanclean flooding. Geo-Marine Letters, 31(5-6), 361-376. https://doi.org/10.1007/ s00367-011-0249-8

Estrada, F., Galindo-Zaldívar, J., Vázquez, J. T., Ercilla, G., d'Acremont, E., Alonso, B., \& Gorini, C. (2018). Tectonic indentation in the central Alboran Sea (westernmost Mediterranean). Terra Nova, 30(1), 24-33.

Faccenna, C., Piromallo, C., Crespo-Blanc, A., Jolivet, L., \& Rossetti, F. (2004). Lateral slab deformation and the origin of the western Mediterranean arcs. Tectonics, 23, TC1012.

Fernández-Ibáñez, F., \& Soto, J. I. (2017). Pore pressure and stress regime in a thick extensional basin with active shale diapirism (western Mediterranean). AAPG Bulletin, 101(2), 233-264. https://doi.org/10.1306/07131615228

Flecker, R., Krijgsman, W., Capella, W., de Castro Martíns, C., Dmitrieva, E., Mayser, J. P., et al. (2015). Evolution of the Late Miocene Mediterranean-Atlantic gateways and their impact on regional and global environmental change. Earth-Science Reviews, 150, 365-392. https://doi.org/10.1016/j.earscirev.2015.08.007

Fossen, H., \& Tikoff, B. (1998). Extended models of transpression and transtension, and application to tectonic settings. Geological Society, London, Special Publications, 135(1), 15-33. https://doi.org/10.1144/GSL.SP.1998.135.01.02

Frizon de Lamotte, D. (1985). La structure du Rif Oriental (Maroc): Rôle de la tectonique longitudinale et importance des fluides. In These Doct. Etat, (pp. 85-03). Paris: Univ. P. et M. Curie.

Galindo-Zaldivar, J., Ercilla, G., Estrada, F., Catalán, M., d'Acremont, E., Azzouz, O., et al. (2018). Imaging the growth of recent faults: The case of 2016-2017 seismic sequence sea bottom deformation in the Alboran Sea (Western Mediterranean). Tectonics, 37(8), 2513-2530. https://doi.org/10.1029/2017TC004941

Gallais, F., Graindorge, D., Gutscher, M. A., \& Klaeschen, D. (2013). Propagation of a lithospheric tear fault (STEP) through the western boundary of the Calabrian accretionary wedge offshore eastern Sicily (Southern Italy). Tectonophysics, 602, 141-152. 
García-Dueñas, V., Balanyá, J. C., \& Martínez-Martínez, J. M. (1992). Miocene extensional detachments in the outcropping basement of the northern Alboran Basin (Betics) and their tectonic implications. Geo-Marine Letters, 12(2), 88-95. https://doi.org/10.1007/BF02084917

Giaconia, F., Booth-Rea, G., Martinez-Martinez, J. M., Azanon, J. M., Storti, F., \& Artoni, A. (2014). Heterogeneous extension and the role of transfer faults in the development of the southeastern Betic basins (SE Spain). Tectonics, 33(12), 2467-2489.

Giaconia, F., Booth-Rea, G., Ranero, C. R., Gràcia, E., Bartolome, R., Calahorrano, A., et al. (2015). Compressional tectonic inversion of the Algero-Balearic basin: Latemost Miocene to present oblique convergence at the Palomares margin (Western Mediterranean). Tectonics, 34(7), 1516-1543. https://doi.org/10.1002/2015TC003861

Gómez de la Peña, L., Ranero, C. R., \& Gràcia, E. (2018). The crustal domains of the Alboran Basin (Western Mediterranean). Tectonics, 37(10), 3352-3377. https://doi.org/10.1029/2017TC004946

Govers, R., \& Wortel, M. J. R. (2005). Lithosphere tearing at STEP faults: Response to edges of subduction zones. Earth and Planetary Science Letters, 236(1-2), 505-523. https://doi.org/10.1016/j.epsl.2005.03.022

Gràcia, E., Grevemeyer, I., Bartolomé, R., Perea, H., Martínez-Loriente, S., Gómez de la Peña, L., et al. (2019). Earthquake crisis unveils the growth of an incipient continental fault system. Nature Communications, 10(1), 3482. https://doi.org/10.1038/s41467-019-11064-5

Gutscher, M.-A., Malod, J., Rehault, J.-P., Contrucci, I., Klingelhoefer, F., Mendes-Victor, L., \& Spakman, W. (2002). Evidence for active subduction beneath Gibraltar. Geology, 30(12), 1071-1074. https://doi.org/10.1130/0091-7613(2002)030<1071:EFASBG>2.0.CO;2

Hanne, D., White, N., \& Lonergan, L. (2003). Subsidence analyses from the Betic Cordillera, southeast Spain. Basin Research, 15, 1-21.

Hidas, K., Garrido, C. J., Booth-Rea, G., Marchesi, C., Bodinier, J.-L., Dautria, J.-M., et al. (2019). Lithosphere tearing along STEP faults and synkinematic formation of lherzolite and wehrlite in the shallow subcontinental mantle. Solid Earth, 10(4), 1099-1121. https://doi.org/ 10.5194/se-10-1099-2019

Iribarren, L., Vergés, J., \& Fernàndez, M. (2009). Sediment supply from the Betic-Rif orogen to basins through Neogene. Tectonophysics, 475(1), 68-84. https://doi.org/10.1016/j.tecto.2008.11.029

Jabaloy-Sánchez, A., Azdimousa, A., Booth-Rea, G., Asebriy, L., Vázquez-Vílchez, M., Martínez-Martínez, J. M., \& Gabites, J. (2015). The structure of the Temsamane fold-and-thrust stack (eastern Rif, Morocco): Evolution of a transpressional orogenic wedge. Tectonophysics, 663, 150-176. https://doi.org/10.1016/j.tecto.2015.02.003

Jabaloy-Sanchez, A., Talavera, C., Gomez-Pugnaire, M. T., Lopez-Sanchez-Vizcaino, V., Vazquez-Vilchez, M., Rodriguez-Peces, M. J., \& Evans, N. J. (2018). U-Pbages of detrital zircons from the Internal Betics: A key to deciphering paleogeographic provenance and tectonostratigraphic evolution, Lithos, 318, 244-266.

Jolivet, L., Augier, R., Faccenna, C., Negro, F., Rimmele, G., Agard, P., et al. (2008). Subduction, convergence and the mode of backarc extension in the Mediterranean region. Bull. Soc. Géol. Fr, 179(6), 525-550. https://doi.org/10.2113/gssgfbull.179.6.525

Jolivet, L., \& Faccenna, C. (2000). Mediterranean extension and the Africa-Eurasia collision. Tectonics, 19(6), $1095-1106$.

Jolivet, L., Faccenna, C., \& Piromallo, C. (2009). From mantle to crust: Stretching the Mediterranean. Earth and Planetary Science Letters, 285, 198-209.

Juan, C., Ercilla, G., Hernández-molina, F. J., Estrada, F., Alonso, B., Casas, D., et al. (2016). Seismic evidence of current-controlled sedimentation in the Alboran Sea during the Pliocene and Quaternary: Palaeoceanographic implications. Marine Geology, 378, 292-311. https://doi.org/10.1016/j.margeo.2016.01.006

Koulali, A., Ouazar, D., Tahayt, A., King, R. W., Vernant, P., Reilinger, R. E., et al. (2011). New GPS constraints on active deformation along the Africa-Iberia plate boundary. Earth and Planetary Science Letters, 308(1-2), 211-217. https://doi.org/10.1016/j.epsl.2011.05.048

Lafosse, M., d'Acremont, E., Rabaute, A., Mercier de Lépinay, B., Tahayt, A., Ammar, A., \& Gorini, C. (2016). Evidence of quaternary transtensional tectonics in the Nekor basin (NE Morocco). Basin Research, 29(4), 470-489. https://doi.org/10.1111/bre.12185

Lafosse, M., Gorini, C., Le Roy, P., Alonso, B., d'Acremont, E., Ercilla, G., et al. (2018). Late Pleistocene-Holocene history of a tectonically active segment of the continental margin (Nekor basin, Western Mediterranean, Morocco). Marine and Petroleum Geology, 97, 370-389. https://doi.org/10.1016/j.marpetgeo.2018.07.022

Leblanc, D. (1980). The Nekor fault and the structure of the eastern Rif (Morocco). Revue de geologie dynamique et de geographie physique, 22(4-5), 267-277.

Leblanc, D., \& Olivier, P. (1984). Role of strike-slip faults in the Betic-Rifian Orogeny. Tectonophysics, 101, 345-355.

Leprêtre, A., Klingelhoefer, F., Graindorge, D., Schnurle, P., Beslier, M. O., Yelles, K., et al. (2013). Multiphased tectonic evolution of the Central Algerian margin from combined wide-angle and reflection seismic data off Tipaza, Algeria. Journal of Geophysical Research: Solid Earth, 118(8), 3899-3916. https://doi.org/10.1002/jgrb.50318

Levander, A., Bezada, M. J., Niu, F., Humphreys, E. D., Palomeras, I., Thurner, S. M., et al. (2014). Subduction-driven recycling of continental margin lithosphere. Nature, 515(7526), 253-256. https://doi.org/10.1038/nature13878

Lonergan, L., \& Johnson, C. (1998). Reconstructing orogenic exhumation histories using synorogenic detrital zircons and apatites: An example from the Betic Cordillera, SE Spain. Basin Res, 10(3), 353-364.

Lonergan, L., \& Mange-Rajetzky, A. M. (1994). Evidence for Internal Zone unroofing from foreland basin sediments, Betic Cordillera, SE Spain. Journal of the Geological Society, 151, 515-529. https://doi.org/10.1144/gsjgs.151.3.0515

Lonergan, L., \& Platt, J. P. (1995). The Malaguide-Alpujarride boundary: A major extensional contact in the Internal Zone of the eastern Betic Cordillera, SE Spain. Journal of Structural Geology, 17(12), 1655-1671.

Maad, N., Le Roy, P., Sahabi, M., Gutscher, M.-A., Hssain, M., Babonneau, N., et al. (2010). Seismic stratigraphy of the NW Moroccan Atlantic continental shelf and Quaternary deformation at the offshore termination of the southern Rif front. Comptes Rendus Geoscience, 342(9), 731-740. https://doi.org/10.1016/j.crte.2010.04.006

Mancilla, F. d. L., Booth-Rea, G., Stich, D., Pérez-Peña, J. V., Morales, J., Azañón, J. M., et al. (2015). Slab rupture and delamination under the Betics and Rif constrained from receiver functions. Tectonophysics, 663, 225-237. https://doi.org/10.1016/j.tecto.2015.06.028

Mancilla, F. d. L., \& Diaz, J. (2015). High resolution Moho topography map beneath Iberia and Northern Morocco from receiver function analysis. Tectonophysics, 663, 203-211. https://doi.org/10.1016/j.tecto.2015.06.017

Mancilla, F. d. L., Heit, B., Morales, J., Yuan, X., Stich, D., Molina-Aguilera, A., et al. (2018). A STEP fault in Central Betics, associated with lateral lithospheric tearing at the northern edge of the Gibraltar arc subduction system. Earth and Planetary Science Letters, 486, 32-40. https://doi.org/10.1016/j.epsl.2018.01.008

Martinez-Garcia, P., Comas, M., Lonergan, L., \& Watts, A. B. (2017). From extension to shortening: Tectonic inversion distributed in time and space in the Alboran Sea, Western Mediterranean. Tectonics, 36(12), 2777-2805. https://doi.org/10.1002/2017TC004489

Martinez-Garcia, P., Comas, M., Soto, J. I., Lonergan, L., \& Watts, A. B. (2013). Strike-slip tectonics and basin inversion in the Western Mediterranean: The Post-Messinian evolution of the Alboran Sea. Basin Research, 25, 361-387. https://doi.org/10.1111/bre.12005 
Martinez-Garcia, P., Soto, J. I., \& Comas, M. (2011). Recent structures in the Alboran Ridge and Yusuf fault zones based on swath bathymetry and sub-bottom profiling: Evidence of active tectonics. Geo-Marine Letters, 31(1), 19-36. https://doi.org/10.1007/ s00367-010-0212-0

Martínez-Martínez, J. M., Booth-Rea, G., Azañón, J. M., \& Torcal, F. (2006). Active transfer fault zone linking a segmented extensional system (Betics, southern Spain): Insight into heterogeneous extension driven by edge delamination. Tectonophysics, 422(1-4), 159-173. https://doi.org/10.1016/j.tecto.2006.06.001

Mauffret, A., Ammar, A., Gorini, C., \& Jabour, H. (2007). The Alboran Sea (Western Mediterranean) revisited with a view from the Moroccan Margin. Terra Nova, 19(3), 195-203. https://doi.org/10.1111/j.1365-3121.2007.00734.x

Mauffret, A., Maillard, A., Pascal, G., Torne, M., Buhl, P., \& Pinet, B. (1992). Long-listening multichannel seismic profiles in the Valencia trough (Valsis 2) and the Gulf of Lions (ECORS): A comparison. Tectonophysics, 203(1-4), 285-304. https://doi.org/10.1016/0040-1951 (92)90228-X

Meghraoui, M., Morel, J. L., Andrieux, J., \& Dahmani, M. (1996). Pliocene and Quaternary tectonics of the Tell-Rif Mountains and the Alboran Sea; a complex zone of continent-continent convergence. Bulletin de La Société Géologique de France, 167, $141-157$.

Michard, A., Chalouan, A., Feinberg, H., Goffé, B., \& Montigny, R. (2002). How does the Alpine belt end between Spain and Morocco? Bull. Soc. Géol. Fr, 173(1), 3-15. https://doi.org/10.2113/173.1.3

Michard, A., Negro, F., Saddiqi, O., Bouybaouene, M. L., Chalouan, A., Montigny, R., \& Goffé, B. (2006). Pressure-temperature-time constraints on the Maghrebide mountain building: Evidence from the Rif-Betic transect (Morocco, Spain), Algerian correlations, and geodynamic implications. Comptes Rendus Geoscience, 338(1-2), 92-114. https://doi.org/10.1016/j.crte.2005.11.011

Mitra, S., \& Namson, J. S. (1989). Equal-area balancing. American Journal of Science, 289, 563-599. https://doi.org/10.2475/ajs.289.5.563

Molina-Aguilera, A., Mancilla, F. d. L., Morales, J., Stich, D., Yuan, X., \& Heit, B. (2019). Connection between the Jurassic oceanic lithosphere of the Gulf of Cádiz and the Alboran slab imaged by Sp receiver functions. Geology, 47(3), 227-230. https://doi.org/10.1130/ G45654.1

Morley, C. (2009). Geometry of an oblique thrust fault zone in a deepwater fold belt from 3D seismic data. Journal of Structural Geology, 31(12), 1540-1555. https://doi.org/10.1016/j.jsg.2009.08.015

Morley, C. K. (1993). Discussion of origins of hinterland basins to the Rif-Betic Cordillera and Carpathians. Tectonophysics, 226, 359-376.

Morley, C. K., Back, S., Van Rensbergen, P., Crevello, P., \& Lambiase, J. J. (2003). Characteristics of repeated, detached, Miocene-Pliocene tectonic inversion events, in a large delta province on an active margin, Brunei Darussalam, Borneo. Journal of Structural Geology, 25(7), 1147-1169. https://doi.org/10.1016/S0191-8141(02)00130-X

Mourgues, R., Lecomte, E., Vendeville, B., \& Raillard, S. (2009). Anexperimental investigation of gravity-driven shale tectonics in progradationaldelta, Tectonophysics, 474(3-4), 643-656. https://doi.org/10.1016/j.tecto.2009.05.003

Muñoz, A., Ballesteros, M., Montoya, I., Rivera, J., Acosta, J., \& Uchupi, E. (2008). Alborán Basin, southern Spain—Part I: Geomorphology. Marine and Petroleum Geology, 25(1), 59-73. https://doi.org/10.1016/j.marpetgeo.2007.05.003

Munteanu, I., Matenco, L., Dinu, C., \& Cloetingh, S. (2011). Kinematics of back-arc inversion of the Western Black Sea Basin. Tectonics, 30(5), n/a. https://doi.org/10.1029/2011TC002865

Neuzil, C. E. (1986). Groundwater flow in low-permeability environments. Water Resources Research, 22(8), 1163-1195. https://doi.org/ 10.1029/WR022i008p01163

Pérez-Belzuz, F., Alonso, B., \& Ercilla, G. (1997). History of mud diapirism and trigger mechanisms in the Western Alboran Sea. Tectonophysics, 282(1-4), 399-422. https://doi.org/10.1016/S0040-1951(97)00226-6

Pérez-Valera, L. A., Rosenbaum, G., Sánchez-Gómez, M., Azor, A., Fernández-Soler, J. M., Pérez-Valera, F., \& Vasconcelos, P. M. (2013). Age distribution of lamproites along the Socovos Fault (southern Spain) and lithospheric scale tearing. Magmatic Response to the Post-Accretionary Orogenesis within Alpine-Himalayan Belt, Lithos, 180-181, 252-263. https://doi.org/10.1016/j.lithos.2013.08.016

Petit, C., Pourhiet, L. L., Scalabrino, B., Corsini, M., Bonnin, M., \& Romagny, A. (2015). Crustal structure and gravity anomalies beneath the Rif, northern Morocco: Implications for the current tectonics of the Alboran region. Geophysical Journal International, 202(1), 640-652. https://doi.org/10.1093/gji/ggv169

Pfiffner, O. A. (2017). Thick-skinned and thin-skinned tectonics: A global perspective. Geosciences, 7(3), 71. https://doi.org/10.3390/ geosciences7030071

Platt, J. P., Kelley, S. P., Carter, A., \& Orozco, M. (2005). Timing of tectonic events in the Alpujarride Complex, Betic Cordillera, southern Spain. Journal of the Geological Society, London, 162, 1-12.

Platt, J. P., Whitehouse, M. J., Kelley, S. P., Carter, A., \& Hollick, L. (2003). Simultaneous extensional exhumation across the Alboran Basin: Implications for the causes of late orogenic extension. Geology, 31(3), 251-254. https://doi.org/10.1130/0091-7613(2003)031<0251: SEEATA $>2.0 . \mathrm{CO} ; 2$

Poujol, A., Ritz, J.-F., Tahayt, A., Vernant, P., Condomines, M., Blard, P.-H., et al. (2014). Active tectonics of the Northern Rif (Morocco) from geomorphic and geochronological data. Journal of Geodynamics, 77, 70-88. https://doi.org/10.1016/j.jog.2014.01.004

Rodriguez-Canero, R., Jabaloy-Sanchez, A., Navas-Parejo, P., \& Martin-Algarra, A. (2018). Linking Palaeozoic palaeogeography of the Betic Cordillera to the Variscan Iberian Massif: New insight through the first conodonts of the Nevado-Filabride Complex. Int J Earth Sci, 107(5), 1791-1806.

Romagny, A., Münch, P., Cornée, J.-J., Corsini, M., Azdimousa, A., Melinte-Dobrinescu, M. C., et al. (2014). Late Miocene to present-day exhumation and uplift of the Internal Zone of the Rif chain: Insights from low temperature thermochronometry and basin analysis. Journal of Geodynamics, 77, 39-55. https://doi.org/10.1016/j.jog.2014.01.006

Rosenbaum, G., Gasparon, M., Lucente, F. P., Peccerillo, A., \& Miller, M. S. (2008). Kinematics of slab tear faults during subduction segmentation and implications for Italian magmatism: Kinematics of slab tear faults. Tectonics, 27(2), n/a. https://doi.org/10.1029/ 2007TC002143

Rosenbaum, G., Lister, G. S., \& Duboz, C. (2002). Reconstruction of the tectonic evolution of the western Mediterranean since the Oligocene. Journal of the Virtual Explorer, 08(paper 6). https://doi.org/10.3809/jvirtex.2002.00053

Rowan, M. G., Peel, F. J., \& Vendeville, B. C. (2004). Gravity-driven fold belts on passive margins. AAPG Memoir, 82, $157-182$.

Sánchez-Gómez, M., Azañón, J. M., Garcia-Duenas, V., \& Soto, J. I. (1999). Correlation between metamorphic rocks recovered from site 976 and the Alpujárride rocks of the western Betics. IProceedings of the Ocean Drilling Program Scientific Results, 161, $307-317$.

Serrano, F., Sanz De Galdeano, C., El Kadiri, K., Guerra-Merchán, A., López-Garrido, A. C., Martín-Martín, M., \& Hlila, R. (2006). Oligocene-early Miocene transgressive cover of the Betic-Rif Internal Zone. Revision of its geologic significance, Eclogae Geol Helv, 99(2), 237-253. 
Sherkati, S., Molinaro, M., Frizon de Lamotte, D., \& Letouzey, J. (2005). Detachment folding in the Central and Eastern Zagros fold-belt (Iran): Salt mobility, multiple detachments and late basement control. Journal of Structural Geology, 27(9), 1680-1696. https://doi.org/ 10.1016/j.jsg.2005.05.010

Somoza, L., Medialdea, T., León, R., Ercilla, G., Vázquez, J. T., Farran, M., et al. (2012). Structure of mud volcano systems and pockmarks in the region of the Ceuta Contourite Depositional System (Western Alborán Sea). Marine Geology, 332-334, 4-26. https://doi.org/10.1016/ j.margeo.2012.06.002

Soto, J. I., Fernández-Ibáñez, F., Fernàndez, M., \& García-Casco, A. (2008). Thermal structure of the crust in the Gibraltar Arc: Influence on active tectonics in the western Mediterranean: Thermal structure of the crust in the Gibraltar Arc. Geochemistry, Geophysics, Geosystems, 9(10), 1-27. https://doi.org/10.1029/2008GC002061

Soto, J. I., Fernández-Ibáñez, F., \& Talukder, A. R. (2012). Recent shale tectonics and basin evolution of the NW Alboran Sea. The Leading Edge, 31(7), 768-775. https://doi.org/10.1190/tle31070768.1

Soto, J. I., Fernandez-Ibanez, F., Talukder, A. R., \& Martinez-Garcia, P. (2010). Miocene shale tectonics in the Northern Alboran Sea (Western Mediterranean). AAPG Memoir, 93, 119-144. https://doi.org/10.1306/13231312M933422

Soto, J. I., Platt, J. P., Sánchez-Gómez, M., \& Azañón, J.-M. (1999). P-Tevolution of the metamorphic basement of the Alboran Sea (site 976) based onthermobarometry and structural observations. Proceedings of the Ocean Drilling Program - Scientific Results, 161, 263-279.

Spakman, W., Chertova, M. V., van den Berg, A., \& van Hinsbergen, D. J. J. (2018). Puzzling features of western Mediterranean tectonics explained by slab dragging. Nature Geoscience, 11(3), 211-216. https://doi.org/10.1038/s41561-018-0066-z

Spakman, W., \& Wortel, R. (2004). A tomographic view on Western Mediterranean Geodynamics. In W. Cavazza, F. Roure, W. Spakman, G. M. Stampfli, \& P. Ziegler (Eds.), The TRANSMED Atlas, The Mediterranean Region from Crust to Mantle (pp. 31-52). Berlin, Heidelberg: Springer

Suppe, J., Connors, C. D., \& Zhang, Y. (2004). Shear fault-bend folding. AAPG Memoir, 82, 303-323.

Talukder, A. R., Comas, M. C., \& Soto, J. I. (2003). Pliocene to Recent mud diapirism and related mud volcanoes in the Alboran Sea (Western Mediterranean). Geological Society, London, Special Publications, 216(1), 443-459. https://doi.org/10.1144/GSL. SP.2003.216.01.29

Teyssier, C., Tikoff, B., \& Markley, M. (1995). Oblique plate motion and continental tectonics. Geology, 23(5), 447-450.

Tikoff, B., \& Teyssier, C. (1994). Strain modeling of displacement-field partitioning in transpressional orogens. Journal of Structural Geology, 16(11), 1575-1588. https://doi.org/10.1016/0191-8141(94)90034-5

Van der Woerd, J., Dorbath, C., Ousadou, F., Dorbath, L., Delouis, B., Jacques, E., et al. (2014). The Al Hoceima Mw 6.4 earthquake of 24 February 2004 and its aftershocks sequence. Journal of Geodynamics, 77, 89-109. https://doi.org/10.1016/j.jog.2013.12.004

Vázquez, M., Asebriy, L., Azimousa, A., Jabaloy, A., Booth-Rea, G., Barbero, L., et al. (2013). Evidence of extensional metamorphism associated to Cretaceous rifting of the North-Maghrebian passive margin: The Tanger-Ketama Unit (External Rif, northern Morocco). Geologica Acta, 11(3), 277-293. https://doi.org/10.1344/105.000001843

Verg\&eacute;s, J., \& Fern\&agrave;ndez, M. (2012). Tethys-Atlantic interaction along the Iberia-Africa plate boundary: The Betic-Rif orogenic system. Tectonophysics, 579, 144-172. https://doi.org/10.1016/j.tecto.2012.08.032

Vissers, R. L. M., Platt, J. P., \& van der Wal, D. (1995). Late orogenic extension of the Betic Cordillera and the Alboran Domain: A lithospheric view. Tectonics, 14(4), 786-803

Vitale, S., Zaghloul, M. N., El Ouaragli, B., Tramparulo, F. D., \& Ciarcia, S. (2015). Polyphase deformation of the Dorsale Calcaire Complex and the Maghrebian Flysch Basin Units in the Jebha area (Central Rif, Morocco): New insights into the Miocene tectonic evolution of the Central Rif belt. Journal of Geodynamics, 90, 14-31. https://doi.org/10.1016/j.jog.2015.07.002

Vitale, S., Zaghloul, M. N., Tramparulo, F. D., \& El Ouaragli, B. (2014). Deformation characterization of a regional thrust zone in the northern Rif (Chefchaouen, Morocco). Journal of Geodynamics, 77, 22-38. https://doi.org/10.1016/j.jog.2013.09.006

Wilcox, R. E., Harding, T. t., \& Seely, D. R. (1973). Basic wrench tectonics. AAPG Bulletin, 57(1), 74-96.

Woodside, J., Ivanov, M., Koelewijn, R., Zeldenrust, I., Shashkin, P., Kenyon, N. H., et al. (2000). Alboran Basin (diapiric province): Sidescan sonar data. Preliminary Results of Geological and Geophysical Investigations during the TTR-9 Cruise of R/V Professor Logachev, Technical Series 56 (pp. 82-84). Intergovernmental Oceanographic Commission.

Wu, S., \& Bally, A. W. (2000). Slope tectonics - comparisons and contrasts of structural styles of saltand shale tectonics of the northern Gulf of Mexico withshale tectonics of offshore Nigeria in Gulf of Guinea. In W. U. Mohriak \& M. Talwani (Eds.). Atlantic rifts and continental margins. American Geophysical Union, Geophysical Monograph Series (Vol. 115, pp. 151-172).

Ziegler, P. A., van Wees, J.-D., \& Cloetingh, S. (1998). Mechanical controls on collision-related compressional intraplate deformation. Tectonophysics, 300(1), 103-129. https://doi.org/10.1016/S0040-1951(98)00236-4 